\title{
Cognitive Approach to Understand the Impact of Conflict of Interests on Accounting Professionals' Decision-Making Behaviour
}

\begin{abstract}
This paper adopts a cognitive approach, by integrating social cognitive theory and throughput model, for examining the process through which conflict of interests affects the accounting professionals' decision-making behaviour. The model has been tested by conducting a quasiexperiment with 105 professionals from the Big Four accounting firms in the UK. The low positive outcome expectancy of compliant decision-making, high perceived difficulty in making compliant decisions and less ethical judgements are evidenced to be the situational cognitive predictors, and high propensity to morally disengage the dispositional cognitive predictor of the likelihood of deviant decision-making behaviour. The proposed cognitive approach provides a novel perspective for investigating decision-making behaviour in situations involving the conflict of interests. To facilitate effective management of conflict of interests, this study suggests implementing behavioural interventions for strengthening the accounting professionals' independence in fact.
\end{abstract}

\section{Keywords:}

conflict of interests, social cognitive theory, throughput model, positive outcome expectancy, perceived difficulty, ethical judgement, propensity to morally disengage, independence in fact. 


\section{Introduction}

The last two decades have witnessed numerous corporate scandals that brought the integrity of accounting professionals and that of the accounting firms into question (Tepalagul and Lin, 2014; Church et al., 2015). Conflict of interests faced by accounting professionals has been playing a central role in such scandals (Bakre, 2007; Clements, Neill and Stovall, 2012; Crump, 2013). According to Thagard (2007), conflict of interests arises when professionals have to make decisions that are biased by their personal interests and they are, therefore, prone to neglecting the interest of others. Despite the increased regulations (Bedard, Deis, Curtis and Jenkins, 2008; Florio, 2012; Williford and Small, 2013), the instances of deviant behaviour due to conflict of interests are still largely pervasive (Ayal and Gino, 2012). For instance, the Big Four accounting firms recently faced heavy fines on account of conflict of interests (Agnew, 2015, Crump, 2015). Although it is evident that the accounting regulation has increased, that the firms do not want to be fined due to reputational concerns, and that the professionals do not want their integrity to be questioned; yet the deviations due to conflict of interests do happen (Moore, Tanlu and Bazerman, 2010). ${ }^{1}$

The extant literature (e.g. Ayal and Gino, 2012; Bazerman and Gino, 2012; Clements, Neill and Stovall, 2012) provides that the so instances of deviant behaviour are largely pervasive due to ineffective management of conflict of interests. The main focus of existing regulation on the accounting professionals' independence in appearance ${ }^{2}$ (Nelson, 2004; Moore, Tanlu and Bazerman, 2010; Bazerman and Gino, 2012; Clements, Neill and Stovall, 2012) and minimal focus on their independence in fact $^{3}$ (Bazerman and Banaji, 2004; Moore, Tetlock, Tanlu and Bazerman, 2006; Guiral, Rodgers, Ruiz and Gonzalo, 2010; Moore, Tanlu and Bazerman, 2010; Ayal and Gino, 2012) are argued to be the potential barriers to the effectiveness of regulation for addressing deviant decision-making behaviour. One of the possible solutions to counter this problem is suggested (e.g. Moore, Tanlu and Bazerman, 2010; Bazerman and

\footnotetext{
${ }^{1}$ It can be argued that the conflict of interests might be avoided by avoiding the transactions or relationships that create these. While some of the recent regulatory reforms (e.g. the Sarbanes-Oxley Act) are meant to avoid the possible conflicts, this is not always possible. Following the interviews with four professionals from the Big Four (Appendix 1), it can conveniently be established that conflicts of interests abound in the professional accounting environment and are usually a natural phenomenon (especially when they are caused by environmental factors including the misaligned rewards and workplace pressures). Therefore, conducting this research becomes necessary because it is still not clear how decision-making behaviour, in the events of conflict of interests, is affected by the interplay of the professionals' mental processes.
}

${ }^{2}$ Independence in appearance is about the public's perception that an accounting professional (and the accounting firm) is objective in conduct and forms impartial judgements (Dopuch, King, Schwartz, and Zhang, 2003; Salehi, 2009).

${ }^{3}$ Independence in fact denotes actual objectivity and a state of mind characterised by the professional's unbiasedness and integrity (Dopuch, King and Schwartz, 2003; Salehi, 2009). 
Gino, 2012) to be the increased focus on the accounting professionals' independence in fact. This, arguably, will facilitate the effective management of conflict of interests.

Some scholars (Guiral, Rodgers, Ruiz and Gonzalo, 2010; Moore, Tanlu and Bazerman, 2010) suggest that the professionals' independence in fact can be addressed through an enhanced understanding of the process through which conflict of interests affects decision-making behaviour. Particularly, there is a need to examine the relationship between conflict of interests and deviant decision-making behaviour, and to understand the role of professionals' mental processes towards their decision-making in the events of conflict of interests (e.g. Nelson, 2004; Chugh, Banaji and Bazerman, 2005; Moore, Tetlock, Tanlu and Bazerman, 2006; Moore, Tanlu and Bazerman, 2010; Ayal and Gino, 2012).

For understanding how a conflict of interests operates at the level of an individual accounting professional, this paper proposes a cognitive model aimed at examining how the conflict of interests affects accounting professionals decision-making behaviour. The model draws on the combination of social cognitive theory and throughput model of decision-making. This approach moves beyond the behaviourists' Stimulus-Response ( $S$-R) Paradigm ${ }^{4}$ (Holland, 2008 ) to the cognitivists' Stimulus-Organism-Response (S-O-R) Paradigm ${ }^{5}$ (Holt et al., 2015). Arguably, the proposed cognitive model tends to offer advantages in terms of better predictive and explanatory power. The resultant improved understanding of how the conflict of interests operates at the level of an individual accounting professional will help propose behavioural interventions for strengthening the professionals' independence in fact and, thus, will contribute towards facilitating effective management of conflict of interests. Thus, the proposed model can potentially be applied for offering the new solution(s) to the longstanding problem of deviant decision-making due to conflict of interests. Following the empirical results, various testable propositions/hypotheses have been offered for the relevant future research to explore further.

In order to test the cognitive model, a web-based quasi-experiment, comprising of four vignettes, has been conducted with 105 professionals from the Big 4 accounting firms in the UK. The statistical technique this study adopts to analyse the empirical data is the Path Analysis which has been performed using SmartPLS 3. Although this research provides empirical

\footnotetext{
4 The S-R Paradigm provides that 'behaviour is the result of stimulus' (Holland, 2008).

${ }^{5}$ The S-O-R Paradigm provides that in the face of stimuli, organisms form cognitive representations (i.e. perceptions and judgements) of the world and respond through their conduct, actions or behaviour' (Holt, et al., 2015).
} 
evidence from the professional accounting environment, the findings may also be applied to law, engineering, medicine and architecture professions (Lo and Field, 2009) that are known to recognise the devastating impacts of conflict of interests. The second and third sections will highlight the relevance of social cognitive theory and the throughput model to the examination of decision-making behaviour in situations involving the conflict of interests. The fourth section will provide the rationale for linking the social cognitive theory with the throughput model, followed by a presentation of the proposed cognitive model in the fifth section. Research design will be included in the sixth section, and the results will be elaborated in the seventh section. Finally, this paper will be concluded in the eighth section.

\section{Social Cognitive Theory}

The social cognitive theory (SCT) establishes that behaviour is regulated through cognitive processes in a given social context and, in this way, provides an account of the sociocognitive determinants of behaviour (Bandura, 1986). The theory suggests that the higher the accounting professionals' perceived difficulty in performing a given task, the lower the likelihood of executing that task. Moreover, if accounting professionals feel that the positive outcomes of executing certain behaviour will outweigh its negative outcomes, they are motivated to adopt such behaviour. SCT further provides that the professionals are likely to display ethical behaviour if they form moral judgements. Importantly, self-efficacy (including perceived difficulty), expectancies and moral judgement are the situational cognitive processes since these are specific to the given context.

Bandura (1986, 2006, 2008) has repeatedly verified the viability of SCT in explaining the reciprocity between environment, cognitive factors and behaviour. The 'person-environment reciprocal interaction' implies that the accounting professionals' cognitions, beliefs and ideas are modified by the external factors from their work environment. Similarly, an environment is, in part, shaped by the manner the professionals solve the problems, form judgements or make decisions. In the 'person-behaviour reciprocal interaction', the cognitive processes and behaviour of a professional interact. The professionals' perception that deviant behaviour is acceptable in their work environment is likely to induce them to deviate from compliant behaviour. Likewise, if the professionals' deviant behaviour is encouraged, they are likely to modify their perception about what constitutes ethical or unethical behaviour. Furthermore, the 'environment-behaviour reciprocal interaction' implies that the workplace pressures to adopt 
deviant behaviour might induce an accounting professional to adopt it and, similarly, the way professionals behave is highly likely to affect the cultural and ethical values prevalent in their work environment (Bandura, 2008).

Figure 1 depicts interactions between the behaviour, the environment and the cognitive factors.

\section{Insert Figure 1: Constructs of Social Cognitive Theory here}

Cognitive theories have been applied to examine a variety of topics in the professional accounting context (Moore, Tetlock, Tanlu and Bazerman, 2006, Guiral, Rodgers, Ruiz and Gonzalo, 2010; Iskandar and Sanusi, 2011; Cabrera-Frias, 2012; Juhari, Sanusi, Rahman and Omar, 2013; Agle, Hart, Thompson and Hendricks, 2014; Wongpinunwatana and Panchoo, 2014; Afifah, Sari, Anugerah and Sanusi, 2015). Since conflict of interests are ethical as well as social in nature (Argandona, 2004), SCT suggests looking at the conflicting interests from the perspective of dynamic interaction between; (i) environment (i.e. situations involving conflict of interests), (ii) cognitive factors (i.e. perceived outcome expectancy, perceived difficulty and ethical judgement) and (iii) behaviour in the event of conflict of interests (i.e. compliant versus deviant). Social cognitive theory can potentially explain how the interplay of environmental factors, cognitive factors and behaviour affect the way an accountant behaves in the events of different conflicts of interests. In this way, the professional accounting firms can get useful insights about managing conflict of interests through; encouragement of desired behavioural change, adjusting the environment or by influencing the personal attitudes.

\section{Throughput Model of Decision-Making}

The throughput model of decision-making (TM) draws on the concept of process thinking which suggests that decision-making behaviour is characterised by the interaction of four concepts, i.e. information (available to an individual), perception (problem-framing and biases), judgement (analysis) and the decision choice. Importantly, perceptions are a source of bias in different decision pathways. As per the throughput model (TM), presented in figure 2 below, there can be at least six pathways to a decision and these vary by the weight a decision maker puts on information and perceptions (Rodgers and AL Fayi, 2018). Perceptions as a direct driver of decision (i.e. $\mathrm{P} \rightarrow \mathrm{D}$ ) introduce intentional bias in decision-making and the other paths involving the role of perceptions (i.e. $\mathrm{P} \rightarrow \mathrm{J} \rightarrow \mathrm{D}, \mathrm{I} \rightarrow \mathrm{P} \rightarrow \mathrm{D}, \mathrm{P} \rightarrow \mathrm{I} \rightarrow \mathrm{J} \rightarrow \mathrm{D}$, and $\mathrm{I} \rightarrow \mathrm{P} \rightarrow \mathrm{J} \rightarrow \mathrm{D}$ ) introduce unintentional bias in decision-making. The $\mathrm{I} \rightarrow \mathrm{J} \rightarrow \mathrm{D}$ path is, however, a bias-free path (Guiral, Rodgers, Ruiz and Gonzalo, 2010). Prior research (e.g. 
Johnson-Laird, 1980; Alloy and Tabachnik, 1984; Anderson, 1985; Rodgers and Gago, 2006; Moore, Tanlu and Bazerman, 2010) has successfully applied throughput model to examine decision-making behaviour in different contexts. Interestingly, each of the decision pathways is dominated by a different moral philosophy (Rodgers, 1997; Rodgers and Gago, 2006; 2009) ${ }^{6}$.

\section{Insert Figure 2: Throughput Model of Decision-Making here}

The accounting professionals often have to deal with a large quantum of complex information (Nielsen, Mitchell and Norreklit, 2015) and, as information processors, their ability to receive, perceive, analyse and to make the decisions is limited. Within the framework of TM, although all the pathways contribute toward decision-making, generally more emphasis is placed on a single pathway. Based on the pathway that dominates, process thinking may lead to different decision choices. Accordingly, this approach might help professionals solve ethical dilemmas by determining which pathways are more likely to lead to compliant decision choices and those that lead to deviant decision choices. Thus, the throughput model is a framework that offers an approach to model ethical decision-making - its ability to capture the decision-making process at the level of an individual is of particular reference to this paper. Since this study seeks to examine the process through which conflict of interests affect accounting professionals' decision-making behaviour, it will be relevant to use throughput model to understand the pathways through which decisions are made and how the biases are introduced in these paths.

\section{Linking Social Cognitive Theory and Throughput Model}

There are many convincing reasons to believe that SCT and TM complement one another and that their combination can help facilitate a better understanding of how a conflict of interests affects decision-making behaviour. Given the complexity of the conflict of interests in the professional environment, there is a growing trend amongst researchers (e.g. Moore and Loewenstein, 2004; Guiral, Rodgers, Ruiz and Gonzalo, 2010; Moore, Tanlu and Bazerman, 2010 ) to use the combination of theories for understanding the phenomena regarding conflicts of interests.

One of the limitations of SCT is that it regards behaviour as an outcome of, mainly, the deliberative efforts (Fishbein and Cappella, 2006; Fishbein, 2008; Conner, 2010) and largely ignores the impact of unconscious thought processes. Similarly, earlier research by Sutton

\footnotetext{
${ }^{6}$ For details on moral philosophies, see Rodgers (2006).
} 
(1998) provided that although the social cognitive models are meant to predict behaviour, they leave much of the variance in behaviour unexplained. Arguably, TM can overcome these limitations due to its ability to explain the possibility of intentional as well as the unintentional bias in the decision-making process (Rodgers, 2006). The throughput model emphasises the central role of perceptions in various pathways to decision-making, and the perceptions are viewed as the sources of unintentional or unintentional bias. The concept of perceptions, however, is very broad and could range from simple cognitive processes to the complex. Social cognitive theory can overcome this limitation by providing specific constructs (Bandura, 2008) representing the perceptions (e.g. outcome expectancy and perceived difficulty) that are of predominant importance in decision-making. Moreover, while SCT simply considers the dynamic interactions between environmental factors, cognitive factors and the behaviour; TM specifically provides the possible cause and effect directions towards the decision-making process in a given context. Therefore, the combination of TM and SCT is expected to offer advantages in terms of better predictive and explanatory power of the resultant models.

Based on the aforementioned arguments, social cognitive theory and the throughput model logically converge into the Stimulus-Organism-Response (S-O-R) Paradigm of behaviour that constitutes the conceptual framework underpinning the cognitive model this paper proposes. This paradigm (Holt et al., 2015) locates organisms' cognitive representation of the world (O) in between the stimulus (S) and response (R). It can, therefore, be argued that the combination of social cognitive theory with the throughput model is the practical depiction of S-O-R paradigm which holds that;

'In the face of stimuli, organisms form cognitive representations (i.e. perceptions and judgements) of the world, and respond through their conduct, actions or behaviour'.

\section{Insert Figure 3: Conceptual Framework (S-O-R Paradigm): Combination of Social}

\section{Cognitive Theory \& Throughput Model of Decision-making here}

With particular reference to this research, the S-O-R paradigm (Figure 3) reflects the following; i. S: Stimulus for an accounting professional derives from the internal and external context for managing conflict of interests. Accordingly, a stimulus is basically represented by environmental factors (as per SCT) or equivalently the situation (as per the information concept in TM). 
ii. O: In the face of information in a given context (i.e. stimulus), the professionals form cognitive representations in terms of the; (i) perceptions towards a situation involving a conflict of interests and (ii) judgement about the alternative decision choices in a given situation. Since the conflict of interests is social in nature (Mills and Bettner, 1992; Argandona, 2004), the perceptions and judgement are essentially the sociocognitive processes.

iii. R: The response is displayed as a decision-making behaviour in reaction to the contextspecific situation involving a conflict of interests. Broadly, it could either be the behaviour in accordance with the primary obligation of the accounting profession (i.e. compliant decisionmaking) or the behaviour in disagreement with the primary interest (i.e. deviant decisionmaking). With specific reference to the accounting ethics research, Cohen and Bennie (2006) provide that the context does matters in ethical decision-making.

Both the social cognitive theory and the throughput model are very well-suited to examine the phenomena at an individual's level. The next section will extend the conceptual framework (i.e. S-O-R Paradigm) to develop the cognitive model.

\section{The Cognitive Model}

This study's conceptual framework, based on S-O-R paradigm (Holt et al., 2015), implies that the professionals' behaviour is an outcome of the cognitive processes that emanate in response to the given situation involving a conflict of interests. Johnson and Hansen (2011) and Florio (2012) assert that the conflict of interests is a widespread ethical problem in the professional accounting environment and, thus, require special attention. To facilitate the accounting firms' efforts towards managing conflicting interests, the proposed model will be aimed at examining the process through which the conflict of interests affects the accounting professionals' decision-making behaviour. Particularly, the purpose is to understand how and why the conflict of interests might lead to deviant decision-making. Accordingly, the cognitive model will include specific variables (and the relationships between them) against each of the components of the conceptual framework, i.e. the stimulus (information), the organism (cognitions) and the response (behaviour).

\subsection{Stimulus (Information)}

In the light of social cognitive theory, the stimulus can be interpreted in terms of the social context, i.e. the circumstances that form setting for the process of managing conflict of interests 
and in terms of which it can be completely understood. Thus, stimulus represents the situational or environmental factors that affect the cognitive processes of a professional which, in turn, influence the resulting behaviours (Bandura, 2008). Similarly, according to the throughput model, stimulus exerts its influence on decision-making behaviour through the information representing the context for managing conflict of interests (Rodgers, 2006). Combining the provisions of both the SCT and TM, it can be argued that the stimulus or information is characterised by the context comprising of the situations involving a conflict of interests. These conflicting interests represent the clash of the accounting profession's primary interest with the professional's secondary interest(s).

\subsubsection{Primary Interest}

Broadly speaking, the primary interest in the accounting profession is about serving in the best interest of the public, including the investors, prospective investors, lending banks, credit agencies and government regulators (Oseni, 2011). Similarly, Pierce (2007) and Clements, Neill and Stovall (2012) provide that the primary responsibility in professional accounting firms is to serve and protect the public interest by reporting on the fairness of client's financial statements. Likewise, the Code of Ethics for Professional Accountants provides that compliance with the fundamental principles of accounting profession (i.e. integrity, objectivity, professional competence $\&$ due care, confidentiality, and professional behaviour) constitutes primary interest of the accounting profession (IESBA, 2015).

\subsubsection{Sources of Secondary Interests}

A detailed review of the literature (e.g. Allen and Siegel, 2002; Moore, Loewenstein, Tanlu and Bazerman, 2003; Moore and Loewenstein, 2004; Beattie, Fearnley and Brandt, 2005; Moore, Cain, Loewenstein and Bazerman, 2005; Moore, Tetlock, Tanlu and Bazerman, 2006; Guiral, Rodgers, Ruiz and Gonzalo, 2010; Moore, Tanlu and Bazerman, 2010; Juhari, MohdSanusi, Rahman and Omar, 2013; Schuchter and Levi, 2015) and some inspections reports including the Audit Quality Inspection Annual Reports 2011 - 2015 (Financial Reporting Council, 2016) reveal three main sources of secondary interests for the accounting professionals. These sources include; (i) the misaligned incentives with roots in temptation for gain, (ii) the misaligned incentives with roots in fear of loss and (iii) the workplace pressures with roots in fear of loss. Furthermore, the Code of Ethics for Professional Accountants recognises various threats (i.e. self-interest, self-review, advocacy, familiarity, and 
intimidation threat) to compliance with the fundamental principles of the accounting profession.

The so recognised threats serve as the sources of secondary interests for the professionals (IESBA, 2015). The code itself and some studies relevant to the conflicts of interests (e.g. Juhari, Mohd-Sanusi, Rahman and Omar, 2013; Ahmad, 2015) indicate that the root causes underlying these threats are, primarily, the misaligned incentives with roots in temptation for gain and/or in fear of loss and the workplace pressures with roots in fear of loss.

\subsubsection{Conflicts of Interests: The Conflict between Primary \& Secondary Interests}

Conflict of interests is said to arise if accounting professionals have any other interest (i.e. secondary interest) that might interfere with their primary responsibility to protect the public trust (Clements, Neill and Stovall, 2012). Thus, conflict of interests refers to a range of scenarios that pose a risk that an individual in question will compromise the professional judgement (Davis, 1993). Similarly, various threats (serving as the sources of secondary interests) interfere with the primary interest of the accounting profession and give rise to the conflict of interests. In such situations, there is a risk of deviation from compliant behaviour (IESBA, 2015). Accordingly, this study defines conflicts of interests as;

" a situation involving a disagreement between the accounting profession's primary interest and the professional's secondary interest(s) which, in turn, leads to the likelihood of deviant

\section{behaviour".}

Irrespective of the specific sources, the majority of the extant literature has used the term 'conflict of interests' to denote all the conflicting interests originating from different sources. However, to achieve valid and robust results, it is essential to consider a broad range of different conflict of interests. So that this research includes the most prevalent categories of conflict of interests, suggestions from the interviews with the four professionals, one each from the Big Four accounting firms, were considered (Appendix 1). Accordingly, the four categories of conflict of interests have been considered in this research, i.e. conflict of interests due to selfinterest threat, that due to intimidation threat, that due to a combination of self-interest and selfreview threats and the conflict of interests due to a combination of self-interest, intimidation, self-review and familiarity threats. The consideration of different categories provides strong empirical evidence for the observed relationships and helps ensure the stability of the results 
across different conflict of interests. This categorisation of conflict of interests builds on the work of Juhari, Mohd-Sanusi, Rahman and Omar (2013).

Therefore, within the bounds of SCT and TM, the stimulus represents the context-specific information about different conflict of interests. With reference to examining the process through which conflicts of interests affects the accounting professionals' decision-making behaviour, the specific variable formalising the first component (i.e. the stimulus) of the conceptual framework is 'conflict of interests' - the independent variable in the proposed cognitive model.

\subsection{Organism (Cognitive Processes)}

With reference to managing conflict of interests, the social cognitive theory and the throughput model draw attention towards two broad categories of cognitive processes, i.e. the perceptions and the judgement. According to the throughput model, perception is about framing a problem according to one's own view of the world. These perceptions introduce biases and shortcut strategies in the decision-making process (Rodgers, 2006). Likewise, social cognitive theory suggests that the positive outcome expectancy of compliant decision-making and the perceived difficulty in making compliant decisions are the two main perceptions of relevance to the professionals' behaviour in the face of conflicting interests. Similarly, the theory also asserts an indispensable role of the judgement (Bandura, 1986; 2006; 2008). Since the conflict of interests is ethical in nature (Finn, Chonko and Hunt, 1988; Mills and Bettner, 1992; Argandona, 2004), social cognitive theory and the throughput model suggest considering the ethical judgements towards the decision-making behaviour.

Thus, within the bounds of SCT and TM, the cognitive processes are characterised by the perceptions and the ethical judgement. With reference to examining the process through which conflict of interests affects accounting professionals' decision-making behaviour, the specific variables formalising the second component (i.e. organism - their cognitive processes) of the conceptual framework are; the 'positive outcome expectancy of compliant decision-making', the 'perceived difficulty in making compliant decisions' and the 'ethical judgement' - the intervening variables in the theoretical model.

\subsection{Response (Behaviour)}


The response in the events of conflicting interests can be broadly categorised into either the deviant or the compliant behaviour. Specifically, the deviant decision represents the decision choice that is in nonconformity with the primary interest of the accounting profession. Likewise, the compliant decision represents the decision choice that is in conformity with the primary interest of the accounting profession. Thus, within the bounds of SCT and TM, the response of the professionals is characterised by the deviant or compliant decision-making behaviour. Since this study seeks to understand the reasons for the prevalence of the professionals' deviant behaviour, the specific variables formalising the third component (i.e. the response) in conceptual framework is the 'likelihood of deviant decision-making behaviour' - the main dependent variable.

Figure 4 represents the proposed cognitive model which is basically the mediation model meant to explain the process or mechanism by which conflict of interests (the independent variable) exerts its impact on the likelihood of decision-making behaviour (the dependent variable). Arguably, this model has the potential to facilitate understanding of the process through which unintentional and/or intentional perceptual biases might increase the likelihood of deviant decision-making behaviour.

\section{Insert Figure 4: The Cognitive Model: Conflict of Interests \& Deviant Decision-Making}

\section{Behaviour here}

Notably, there are two main reasons to include the 'likelihood of decision-making behaviour' (and not simply the 'decision-making behaviour') as a variable of interest in the proposed model. First, this research tends to view conflict of interests through the lens of behavioural risk management, and any risk situation poses uncertainty in terms of the increase or decrease in the likelihood of occurrence (or non-occurrence) of the intended behaviour, objectives, events or consequences (see, ISO 31000:2009). The definition of conflict of interests, as per this study, also highlight the likelihood of deviant behaviour in situations involving the conflicts between primary and secondary interest(s). Secondly, the behavioural research (e.g. Sniehotta, Schwarzer, Scholz, and Schuz, 2005; Baker-Eveleth and Stone, 2008; Brown, Littlewood and Vanable, 2013; Cheng and Chu, 2013; Khan, Panatik, Saat and Perveen, 2013) strongly asserts that the individual's perceived likelihood of engaging in a given behaviour (also termed, behavioural intention) is the most proximate predictor of their actual behaviour.

\section{Research Design}


Figure 5 presents the cognitive model that has been tested for empirical evidence of the process through which the conflict of interests affects the deviant decision-making behaviour, and of the role of accounting professionals' mental processes towards their deviant decision-making.

\section{Insert Figure 5: Model Testing _ Conflict of Interests \& Deviant Decision-Making Behaviour here}

Occupational self-efficacy (OSE) and propensity to morally disengage (PMD) are the dispositional cognitive processes that have been included as the control variables in the tested model. Extant research (e.g. Iskandar and Sanusi, 2011; Palmer, 2013; Agle, Hart, Thompson and Hendricks, 2014; Afifah, Sari, Anugerah and Sanusi, 2015) suggest the negative effect of the professional's occupational self-efficacy on the adoption of unethical behaviour. Therefore, a negative relationship is expected between the professionals' occupational self-efficacy and their likelihood of deviant decision-making behaviour. Moreover, literature (e.g. Moore et al., 2012; Cabrera-Frias; 2012) provides that an individual's propensity to morally disengage is negatively related to ethical behaviour and positively to the unethical or deviant decisionmaking behaviour. Therefore, a positive relationship is expected between the professionals' propensity to morally disengage and their likelihood of deviant decision-making behaviour.

\subsection{Participants}

The participants comprised of 105 professionals from the Big Four accounting firms in the UK. There were several reasons for this choice of the sample - for instance, the Big Four are the largest professional services networks, the mismanagement of conflict of interests in the Big Four is an active issue of concern and the Big Four are trendsetters in the professional accounting world (Agnew, 2015; Loxton, 2015). An initial list of total 3295 accounting professionals was created using the 'Register of Statutory Auditors'. Out of these, email addresses of 2283 professionals could be arranged, using google. Following the initial request for participation, two reminders and additional correspondence with some of the participants, a total of 105 complete responses were received ${ }^{7}$. The participants from each of the Big Four have fairly equal distribution in the study's sample. Out of the total 105 respondents, 22 belong

\footnotetext{
${ }^{7}$ The research instrument was emailed to a total of 2283 professionals. A total of 110 emails bounced and 2173 got sent, out of which only 591 emails got opened (the rest of the emails, as suggested by the Qualtrics team, ended up in the spam/junk folder of the recipients). Out of the 591, the 239 were the opt-out, refusal and incomplete responses and 105 the complete responses. The response rate based on 591 opened emails was $18 \%$ (i.e. 105/591) which, according to various scholars (e.g. Bryman and Bell, 2007; Dillman, Smyth and Christian, 2008; Saunders, Thornhill and Lewis, 2009) is acceptable in case of the research based on convenience sampling.
} 
to Deloitte, 27 to EY, 30 to KPMG, and 26 are from PricewaterhouseCoopers. $79 \%$ of the participants are partners, $79 \%$ have more than 20 years of work experience, $82 \%$ are more than 40 years old and $81 \%$ are male.

\subsection{Quasi-Experiment}

This study conducted a web-based repeated measures quasi-experiment, powered by Qualtrics, which comprised of the four vignettes. The vignettes have been informed by the Code of Ethics for Professional Accountants (Johnson and Hansen, 2011; IESBA, 2015), the relevant literature (e.g. Juhari, Mohd-Sanusi, Rahman and Omar, 2013; Financial Reporting Council, 2016) and the interviews (Appendix 1) conducted with four professionals from the Big Four accounting firms. The final version of the vignettes is the result of rigorous pilot testing. The hypothetical scenarios for all the four vignettes have been derived from Ethical Dilemmas Case Studies developed by the UK and Ireland's Consultative Committee of Accountancy Bodies, 2011. Importantly, all the case studies are followed by clear guidance on 'compliant versus deviant decision' in the given dilemma situations and the same have been included in this study's vignettes. Thus, the decision on what constitutes compliant or deviant behaviour in any given situation is not susceptible to the researcher's bias.

Notably, all the vignettes are intentionally designed to be simple because 'task complexity' has been treated as one of the controls. Therefore, any change in response to the vignette scenarios cannot be attributed to the difficulty level of the task. Some relevant research (e.g., Moore, Cain, Loewenstein and Bazerman, 2005; Moore, Tetlock, Tanlu and Bazerman, 2006; Guiral, Rodgers, Ruiz and Gonzalo, 2010; Moore, Tanlu and Bazerman, 2010; Juhari, Mohd-Sanusi, Rahman and Omar, 2013) seemingly supports this approach for examining the ethics-related concerns in the professional accounting environment. Appendix 2 presents the research instrument used for data collection.

\subsection{Operationalisation, Manipulation and Measurement of Variables}

\subsubsection{Independent Variable: Conflict of interests (CoI)}

Building on the work of Juhari, Mohd-Sanusi, Rahman and Omar (2013), conflict of interests is the independent variable which has been manipulated through different threats to compliance with the fundamental principles of professional ethics. The vignette 1 involves conflict of interests due to self-interest threat - CoI-1, vignette 2 includes conflict of interests due to 
intimidation threat - CoI-2, vignette 3 involves conflict of interests due to a combination of self-interest and self-review threats - CoI-3, and vignette 4 is about the conflict of interests due to a combination of self-interest, intimidation, self-review and familiarity threats - CoI-4. As such, CoI-1, CoI-2, CoI-3 and CoI-4 represent the four categories of conflict of interests considered in this study.

\subsubsection{Dependent Variables: Likelihood of Deviant Decision-Making Behaviour (DD)}

In all the four vignettes, DD has been operationalised as the likelihood of making a deviant decision in the event of a conflict of interests. The deviant decision represents the decision choice that is in nonconformity with the primary interest of the accounting profession. In case of all the vignettes, DD has been measured using 5-points Likert item with ' 1 ' representing deviant decision-making as extremely unlikely and ' 5 ' as extremely likely.

\subsubsection{Intervening Variables: Positive Outcome Expectancy (POE), Perceived Difficulty (PD) and Ethical Judgement (EJ)}

In all the four vignettes, POE has been operationalised as the professionals' expectation that the overall positive outcomes of compliant decision-making will outweigh its overall negative outcomes. PD has been operationalised as the professionals' perceived difficulty in making a compliant decision. Moreover, EJ has been operationalised as the participants' judgement about the ethicality of the decision choices.

POE has been measured as the self-reported level of agreement/disagreement with the expectation that the overall positive outcomes of compliant decision-making will outweigh its overall negative outcomes. 5-points Likert item has been used with ' 1 ' representing strong disagreement and ' 5 ' the strong agreement. Similarly, PD has been measured as the selfreported level of perceived difficulty/ease in making the compliant decisions. 5-points Likert item has been used with ' 1 ' representing the perception of difficulty level in making compliant decisions as 'very easy' and ' 5 ' as 'very difficult'. Moreover, ethical judgement (EJ) has been measured by the participants' judgement about the ethicality of the decision choices, in all the given situations of conflicting interests. Three broad decision choices are included with varying levels of ethicality on a continuum - one of these represent the least ethical choice, i.e. deviant decision (coded ' 1 '), another representing the less ethical decision, i.e. neither deviant not compliant (coded '2') and the third the most ethical, i.e. compliant decision (coded ' 3 '). 


\subsubsection{Control Variables: Occupational Self-Efficacy (OSE) and Propensity to Morally Disengage (PMD)}

OSE has been introduced in the cognitive model as a control variable that represents a dispositional trait. It has been operationalised as the professional's perceived ability to successfully cope with the occupation-related challenges and tasks. OSE has been measured using a short version of the Occupational Self-Efficacy Scale, proposed by Rigotti, Schyns and Mohr (2008). Similarly, PMD has also been introduced in the cognitive model as a control variable that represents a dispositional trait. It has been operationalised as the professional's tendency to consider unethical behaviour as ethically acceptable. PMD was measured using a short version of the Propensity to Morally Disengage Scale, proposed by Moore et al. (2012). The lower scores on both the occupational self-efficacy and the propensity to morally disengage scales indicate less of the respective traits. Since OSE and PMD have been included as the dispositional factors, these remain context-free. This implies that OSE and PMD for a particular participant will be same across all the four experimental vignettes.

\subsection{Model Assessment}

Using Smart PLS 3, the PLS-based path analysis has been adopted as a statistical technique to analyse the empirical data collected through the repeated measures experiment with 105 professionals from the Big 4 accounting firms. Each of the professionals was exposed to four scenarios representing four different categories of the conflict of interests (i.e. CoI-1, CoI-2, CoI-3 and CoI-4). Thus, the total observations are $105 * 4=420$. Separate models have been run for each of the four categories of conflict of interests, i.e. CoI-1, CoI-2, CoI-3 and CoI-4. The model was, first, assessed through examining different criteria (Appendix 3) including the coefficients of determination $\left(R^{2}\right)$, path coefficients $(\beta)$, effect size $\left(f^{2}\right)$, predictive relevance $\left(\mathrm{Q}^{2}\right)$, goodness of model fit (using standardized root mean square residuals - SRMR) and the multicollinearity (using variance inflation factor-VIF). Following the guidance provided by various scholars (e.g. Roth, 2012; Hair, Ringle and Sarstedt, 2013; Henseler, Hubona and Ray, 2016), the assessment results provided that the estimates obtained from this study's model are meaningful and that the conclusions drawn on them are not susceptible to doubtfulness.

\section{Results}


The significance of the path coefficients has been reported using the $p$-values instead of the $t$ values. The $p$-values associated with path coefficients reflect the degree of relationship and also the power of the test. Compared to $t$ values, the $p$-values are more meaningful when testing the model. Furthermore, the bootstrapping procedure in SmartPLS 3 relies on random samples drawn from the data and the $t$ value changes every time the PLS algorithm is run to test the model - the change, however, is not substantial enough to convert the significant relationship into nonsignificant, and vice versa (Kock, 2011).

Consistent with the approach followed by Guiral, Rodgers, Ruiz and Gonzalo (2010), the results regarding the 'bias due to conflict of interests' are based on two types of effects, i.e. path coefficients $(\beta)$ to capture the variation in predicted variable for a unit change in the predictor, and the correlation coefficients $(r)$ to capture the strength of relationships. Although they considered either ' $\beta$ ' (where relationships were hypothesised) or ' $r$ ' (where relationships were not hypothesised), this study considers both the coefficients. Accordingly, in order for a relation between two variables to hold significant effect, both the $\beta$ and $\mathrm{r}$ should be significant at, at least, $\mathrm{p}<0.10$. The rationale to consider both the $\beta$ and $\mathrm{r}$ simultaneously can be attributed to the difference between the goals of the regression and that of the correlation. Field (2009) provides that while regression is meant to find the best line that predicts dependent variable from the independent variable and indicates the pattern of relationship, the correlation coefficient is meant to denote the strength of association between the variables.

\subsection{Empirical Findings}

The tables 1 to 4 include the path coefficients $(\beta)$ and the correlation coefficients (r) for the tested cognitive model.

Insert Table 1: Conflict of interests due to Self-interest threat (CoI-1) here

Insert Table 2: Conflict of interests due to Intimidation Threat (CoI-2) here

Insert Table 3: Conflict of interests due to Self-Interest and Self-Review Threats (CoI-3) here

Insert Table 4: Conflict of interests due to Self-Interest, Intimidation, Self-Review and Familiarity Threats (CoI-4) here

\subsubsection{Conflict of Interests (CoI) \& Deviant Decision-Making Behaviour (DD)}


The results indicated that CoI-1 and CoI-3 are negatively and significantly related to DD, CoI2 is positively and significantly related to DD and there is positive but a nonsignificant relationship between CoI-4 and DD. The results for different categories of conflict of interests are inconsistent and there might be more variations for the other categories not explicitly included in this study. These results are, however, justifiable because this study has considered different categories of $\mathrm{CoI}$ as the 'risks' that are 'expected to threaten' the adoption of compliant behaviour (Davis, 1993; Moore, Tetlock, Tanlu and Bazerman, 2006; Thagard, 2007; Lo and Field, 2009; Florio, 2012), but do not always result in the deviant behaviour. Nevertheless, these inconsistent results call for probing into more details of the process through which conflict of interests operates at the level of an individual accounting professional. In this regard, the literature relevant to the cognitive psychology of conflict of interests (Rodgers and Gago, 2001; 2006; Chugh, Banaji and Bazerman, 2005; Rodgers, 2006; 2009, Guiral, Rodgers, Ruiz and Gonzalo, 2010; Moore, Tanlu and Bazerman, 2010), the social cognitive theory and the throughput model suggest that the relationship between the CoI (i.e. stimuli) and the DD (i.e. response) can only be explained by taking into account the intervening cognitive processes (i.e. POE, PD and EJ).

The empirical results provide that;

- "Conflict of interests in professional accounting firms is related to the professionals' likelihood of deviant decision-making behaviour".

\subsubsection{Conflict of Interests (CoI) \& Cognitive Processes (POE, PD and EJ)}

The results indicated that CoI-1 and CoI-3 are positively and CoI-2 negatively related to POE and EJ. There is a nonsignificant relationship between CoI-4 and POE, and positive between CoI-4 and EJ. Moreover, CoI-1 and CoI-4 are negatively and CoI-2 positively related to PD, while there is a nonsignificant relationship between CoI-3 and PD. These mixed results are consistent with the prior studies providing that the perceptions are largely subjective and that different individuals could perceive the same situation differently. Similarly, since judgement implies subjective and deliberate information processing strategies, two or more individuals could form different judgements in the same ethical situation (Rodgers, 2006; 2009; Rodgers and Gago, 2001; 2006; Guiral, Rodgers, Ruiz and Gonzalo, 2010; Cvejic, Lloyd and VollmerConna, 2016). In the cases where CoI is significantly related to the cognitive processes, the decision-making process is driven by the conflict of interests. Moreover, where CoI has a nonsignificant effect, the decision-making process is driven by the professional's POE and/or 
PD. Specifically, the significant relationship between CoI and EJ implies that the information surrounding $\mathrm{CoI}$ is not disregarded but is subjected to a thorough analysis at the judgement stage of decision-making.

Interestingly, the results demonstrated for the relationship between CoI and the cognitive processes seemingly connect to the results evidenced for the relationship between CoI and DD. The results indicate that the conflict of interests decreases the likelihood of deviant decisionmaking if the accounting professionals expect the positive outcomes of making compliant decisions to outweigh its negative outcomes, form a judgement that a given compliant decision choice is the most ethical course of action, and perceive less difficulty in making the given compliant decision. Similarly, conflict of interests increases the likelihood of deviant decisionmaking behaviour if the accounting professionals expect the negative outcomes of making compliant decisions to outweigh its positive outcomes, form a judgement that a given compliant decision choice is the least (or less) ethical course of action, and perceive high difficulty in making the given compliant decision. Therefore, as provided by the social cognitive theory and the throughput model, the relationship between conflict of interests (i.e. stimulus) and the decision-making behaviour (i.e. response) is affected by POE, PD and EJ as the intervening cognitive processes.

The empirical results provide that;

- "Conflict of interests in professional accounting firms is related to the professionals' positive outcome expectancy of compliant decision-making”.

- "Conflict of interests in professional accounting firms is related to the professionals" perceived difficulty in making a compliant decision”.

- "Conflict of interests in professional accounting firms is related to the professionals' ethical judgement".

\subsubsection{Cognitive Processes (POE, PD and EJ) \& Deviant Decision-Making Behaviour (DD)}

The results indicated that POE and EJ are negatively and PD positively related to DD in case of CoI-1, CoI-2, CoI-3 and CoI-4. The results are consistent with the literature examining the relationship between the cognitive processes (POE, PD and EJ) and behaviour in a wide variety of contexts (e.g. Garcia and Mann, 2003; Sullivan, 2004; Zebracki and Drotar, 2004; Sniehotta, 
Schwarzer, Scholz and Schüz, 2005; Bandura, 2006; Cohen and Bennie, 2006; Rodgers and Gago, 2006; Sauers, Ballantine and Kennedy, 2006; Smith, Simpson and Huang, 2007; BakerEveleth and Stone, 2008; Rodgers, 2009; Brown, Littlewood and Vanable, 2013; Cheng and $\mathrm{Chu}, 2013)$. The results indicate that the likelihood of deviant decision-making behaviour is low in case of the professionals who expect the positive outcomes of making compliant decision to outweigh its negative outcomes, form a judgement that compliant decision choice is the most ethical course of action and perceive less difficulty in making a compliant decision. Similarly, the likelihood of deviant decision-making behaviour is high where the professionals expect the negative outcomes of compliant decision-making to outweigh its positive outcomes, form a judgement that compliant decision choice is not the most ethical course of action (or that deviant decision choice is the most ethical) and perceive high difficulty in making a given compliant decision. Specifically, low POE, high PD and low EJ are demonstrated to be the situational cognitive predictors of DD.

In agreement with the social cognitive theory's concept of person-behaviour interaction, the significant roles of POE, PD and EJ towards DD imply that the accounting professionals' decision-making is affected by their perceptions and judgement (Bandura, 2006; 2008). The results are also relatable to the throughput model of decision-making (Rodgers, 2006; 2009; Rodgers and Gago, 2001; 2006; Guiral, Rodgers, Ruiz and Gonzalo, 2010). For instance, the model provides that there can be various pathways to a particular decision - the significant relationship between the cognitive processes and the DD implies that the accounting professionals' deviant decision-making is an outcome of the pathways characterised by the important role of their POE, PD and EJ.

The empirical results provide that;

○ "In the events of conflict of interests in professional accounting firms, the professionals' positive outcome expectancy of compliant decision-making is negatively related to their likelihood of deviant decision-making behaviour".

○ "In the events of conflict of interests in professional accounting firms, the professionals' perceived difficulty in making a compliant decision is positively related to their likelihood of deviant decision-making behaviour".

○ "In the events of conflict of interests in professional accounting firms, the 
professionals' ethical judgement is negatively related to their likelihood of deviant decision-making behaviour".

\subsubsection{The interrelationship of the Cognitive Processes (POE, PD and EJ)}

The results indicated that POE is negatively related to PD and positively to EJ across CoI-1, CoI-2, CoI-3 and CoI-4. Moreover, PD is negatively related to EJ across all the categories of CoI. The demonstrated results are consistent with the extant literature that relates POE to PD and EJ (e.g. Corcoran, 1991; 1995; Garcia and Mann, 2003; Zebracki and Drotar, 2004; Sniehotta, Schwarzer, Scholz and Schüz, 2005; Smith, Simpson and Huang, 2007; BakerEveleth and Stone, 2008; Lin, Ko and Wu, 2008; Williams, 2010; Charles, 2011; Iskandar and Sanusi, 2011; Brown, Littlewood and Vanable, 2013; Cheng and Chu, 2013; Agle, Hart, Thompson and Hendricks, 2014; Wongpinunwatana and Panchoo, 2014; Afifah, Sari, Anugerah and Sanusi, 2015). The results indicate that the accounting professionals who expect compliant decision-making to have more positive than the negative outcomes are likely to perceive lower difficulty in making compliant decisions and to form highly ethical judgements. Similarly, the higher perceived difficulty in making compliant decisions and the formation of less ethical judgements is probable if the professionals expect that compliant decision-making has less positive than the negative outcomes.

In accordance with the social cognitive theory (Bandura, 2006; 2008) and that of the throughput model (Rodgers and Gago, 2001; 2006; Rodgers, 2006; 2009; Guiral, Rodgers, Ruiz and Gonzalo, 2010), these discussions support the indispensable interconnectedness of the conflict of interests with the accounting professionals' cognitive processes (i.e. POE, PD and EJ) and their behaviour. This implies that, in the events of conflict of interests, the accounting professionals' mental cognitive processes play an important role in their decision-making behaviour.

The empirical results provide that;

- "In the events of conflict of interests in professional accounting firms, the professionals' positive outcome expectancy of compliant decision-making is negatively related to their perceived difficulty in making a compliant decision".

○ "In the events of conflict of interests in professional accounting firms, the professionals' positive outcome expectancy of compliant decision-making is 
positively related to their ethical judgement".

- "In the events of conflict of interests in professional accounting firms, the professionals' perceived difficulty in making a compliant decision is negatively related to their ethical judgement".

\subsubsection{Bias due to Conflict of Interests (CoI)}

In case of all the categories of conflict of interests, the overall results indicate that deviant decision-making is likely to be prone to perceptual bias due to the interference of POE and/or $\mathrm{PD}$ through the $\mathrm{CoI} \rightarrow \mathrm{POE} \rightarrow \mathrm{DD}, \mathrm{CoI} \rightarrow \mathrm{PD} \rightarrow \mathrm{DD}, \mathrm{CoI} \rightarrow \mathrm{POE} \rightarrow \mathrm{EJ} \rightarrow \mathrm{DD}, \mathrm{PD} \rightarrow \mathrm{EJ}$ $\rightarrow$ DD and the POE $\rightarrow$ DD paths. Particularly, the perceptions as a direct driver of decision (i.e. the POE $\rightarrow$ DD path) introduce intentional bias, and the other paths involving the role of perceptions introduce unintentional bias in the decision-making. The pathways to decisionmaking are characterised by particular moral philosophies (Rodgers and Gago, 2001; 2006, Rodgers, 2006; 2009). For instance, the $\mathrm{CoI} \rightarrow \mathrm{POE} \rightarrow \mathrm{DD}$ and $\mathrm{CoI} \rightarrow \mathrm{PD} \rightarrow \mathrm{DD}$ are underpinned by the 'ethical relativism', $\mathrm{CoI} \rightarrow \mathrm{POE} \rightarrow \mathrm{EJ} \rightarrow \mathrm{DD}$ by the 'ethics of care', $\mathrm{PD}$ $\rightarrow \mathrm{EJ} \rightarrow \mathrm{DD}$ by the 'deontology' and the $\mathrm{POE} \rightarrow \mathrm{DD}$ path is characterised by the 'psychological egoism'. Resultantly, such ethical predispositions lead to a wide variety of biases in the decision-making process.

The demonstrated results comply with the extant literature which supports the idea that the conflict of interests leads to bias in decision-making (Greene et al., 2001; Casebeer and Churchland, 2003; Chugh, Banaji and Bazerman, 2005; Ashkanasy, Windsor and Trevino, 2006; Moore, Tetlock, Tanlu and Bazerman, 2006; Green, Ha and Bullock, 2010; Guiral, Rodgers, Ruiz and Gonzalo, 2010). Accordingly, the decision outcome in any given conflict of interests' situations is largely affected by the accounting professionals' subjective experience. These biases serve as the psychological and cognitive barriers which, in turn, threaten the accounting professional's independence in fact. The accounting standards require the professionals to adopt a bias-free analytical pathway to decision-making, i.e. $\mathrm{CoI} \rightarrow \mathrm{EJ} \rightarrow \mathrm{DD}$ (Guiral, Rodgers, Ruiz and Gonzalo, 2010). Since this path does not involve the role of professionals' perceptions, its adoption implies that the information surrounding conflict of interests (CoI) is subjected to the detailed analysis (EJ), which leads the professionals to refrain from deviant decision-making (DD) or alternatively to adopt compliant decision-making behaviour (Rodgers and Gago, 2001; 2006; Rodgers, 2009). 
The results reveal the significance of perceptions which implies that, in situations involving a conflict of interests, the accounting professionals are prone to disregarding the adoption of the analytical pathway and, thereby, increasing the likelihood of deviant decision-making. Therefore, the conflict of interests plays a biasing role by introducing the perceptual biases in the decision-making process. POE and PD serve as the sources of said perceptual biases that have been demonstrated to be, largely, unintentional - this implies that, in the events of conflict of interests, the deviations from compliant behaviour can even occur undesirably.

The empirical results provide that;

O "In the events of conflict of interests in professional accounting firms, the professionals' decision-making behaviour will be prone to bias due to the interference of their positive outcome expectancy with the analytical pathway to the deviant decision".

○ "In the events of conflict of interests in professional accounting firms, the professionals' decision-making behaviour will be prone to bias due to the interference of their perceived difficulty with the analytical pathway to the deviant decision".

\subsubsection{Occupational Self-Efficacy (OSE) \& Deviant Decision-Making Behaviour (DD)}

A negative relationship was expected between the professionals' OSE and DD. The empirical results, however, indicate that there is a nonsignificant relationship between OSE and DD for all the categories of conflict of interests. The demonstrated results, therefore, are not consistent with the literature that suggests a negative relationship between an accounting professional's OSE and DD (MacNab and Worthley, 2008; Iskandar and Sanusi, 2011; Palmer, 2013; Agle, Hart, Thompson and Hendricks, 2014, Afifah, Sari, Anugerah and Sanusi, 2015). This nonsignificant relationship can be related to the provision by Bandura $(1986 ; 2006 ; 2008)$ that self-efficacy is largely a context-specific process. Since situations involving a conflict of interests are also context-specific (Cohen and Bennie, 2006), the results suggest that the accounting professionals' situational cognitive processes (i.e. POE, PD and EJ) had a dominant impact on their deviant decision-making behaviour.

\subsubsection{The Propensity to Morally Disengage (PMD) \& Deviant Decision-Making Behaviour (DD)}


In the events of conflict of interests, the professionals' propensity to morally disengage (PMD) was expected to be positively related to their likelihood of deviant decision-making behaviour (DD). The empirical results also indicate that there is a significant positive relationship between PMD and DD for all the categories of conflict of interests. The demonstrated results, therefore, are consistent with the literature that suggests a positive relationship between an accounting professional's PMD and DD (Bandura, Barbaranelli, Caprara and Pastorelli, 1996; Bandura, 1999; 2002; Bandura, Caprara and Zsolnai, 2000; Moore, 2008; Cabrera-Fria, 2012; Moore et al., 2012). This significant relationship implies that the accounting professionals' PMD is as important as are the situational cognitive processes (i.e. POE, PD and EJ), in affecting their likelihood of deviant decision-making behaviour. Specifically, low PMD is demonstrated to be the dispositional cognitive predictor of deviant decision-making behaviour.

\subsection{Discussion of Findings}

Building on the empirical findings, this section will highlight the main contributions of this study in terms of its implications, the possible solutions that can be derived from the knowledge this study generates and, importantly, how increased understanding of the involvement of cognitive processes might enable accounting firms to achieve higher degrees of independence in fact.

The low positive outcome expectancy, high perceived difficulty, and less ethical judgements have been evidenced to be the situational cognitive predictors of deviant decision-making. Moreover, the dispositional cognitive predictor is the high propensity to morally disengage. In relation to managing conflict of interests, the results suggest that the accounting firms should increase their efforts towards encouraging, amongst professionals, the high positive outcome expectancy of compliant decision-making, low perceived difficulty in making compliant decisions, the formation of highly ethical judgements, and the low propensity to morally disengage. Social cognitive theory suggests that the desired behavioural change may be encouraged by introducing adjustments to the environment, or by influencing personal attitudes.

Importantly, the findings also provide that decision-making, in the face of a conflict of interests, is prone to the perceptual biases (i.e. due to POE and PD) through various pathways - however, this is not necessarily the bad news. Thankfully the throughput model's process thinking approach, drawing on the interaction of information, perception, judgement and decision 
choice, provides a constructive way of formulating thoughts and biases into a successful strategy, with ultimate focus on decreasing the likelihood of deviant decision-making behaviour (Rodgers and Gago, 2001; 2006; Rodgers and AL Fayi, 2018). The immediate usefulness of process thinking is that it can alert individuals of the particular pathway they use to arrive at a decision. Generally, success across the pathway journey is achieved when an individual and those governing the individuals' behaviour are aware of the obstacles they encounter during decision-making (Rodgers, 2006; 2009; Guiral, Rodgers, Ruiz and Gonzalo, 2010). These provisions are useful in developing the behavioural interventions for facilitating effective management of conflict of interests.

Therefore, the empirical findings reveal useful insights for addressing the accounting professionals' likelihood of deviant decision-making behaviour due to conflict of interests. These insights can, possibly, be combined into the behavioural interventions to be incorporated in the framework(s) for managing conflict of. The findings suggest that some of the possible solutions and steps that the professional accounting bodies might implement towards establishing the context, assessment, treatment, control and monitoring of the conflict of interests could be; promoting a culture of strong ethics and compliance, using electronic decision aids for measuring the level of professionals' cognitive predictors/processes, quality control inspections, conducting trainings to raise awareness of the psycho-cognitive barriers to decision-making, and continuous review and improvement in the overall risk management process.

Since all the insights revealed by this study's empirical results are directly relevant to the professionals' state of mind and is about their unbiasedness and objectivity in the events of a conflict of interests, the interventions developed on the basis of these insights will help strengthen accounting professionals' independence in fact. Arguably (Moore, Tanlu and Bazerman, 2010; Bazerman and Gino, 2012; Williford and Small, 2013), the enhancement of independence in fact will facilitate effective management of conflict of interests in the professional accounting firms. Therefore, the findings of this study enhance our understanding of the process through which conflict of interests affects accounting professionals' decisionmaking behaviour and, thus, contribute towards understanding how the conflict of interests operate at the level of an individual accounting professional.

Notably, the results against different categories of conflict of interests converged to the same insights and conclusions which provides the evidence that, in principle, all the categories of 
conflict of interests affect decision-making in the same way and are governed in a similar manner. Therefore, the findings of this study can be generalised across various categories of conflict of interests.

\section{Conclusions}

This paper developed and tested a cognitive model, by integrating social cognitive theory with the throughput model, to provide empirical evidence for the process through which conflict of interests affects the accounting professionals' decision-making behaviour. The main findings were that the relationship between the conflict of interests and the accounting professionals' likelihood of deviant decision-making behaviour is, in part, governed through the agency of the professionals' situational cognitive processes (i.e. positive outcome expectancy of compliant decision-making, perceived difficulty in making compliant decisions, and judgements about the ethicality of compliant decision choices). Furthermore, the professionals' propensity to morally disengage (i.e. a dispositional cognitive process) was also evidenced to affect their likelihood of decision-making behaviour. Additionally, decision-making in the face of a conflict of interests is prone to the perceptual biases that interfere with decision-making through different pathways. By allowing examination of the role of the mental processes and the biases in decision-making behaviour, the proposed cognitive model enables addressing the professionals' independence in fact.

This study holds significance since it has been conducted in response to the repeated calls of several experts in the field (Moore, Tetlock, Tanlu and Bazerman, 2006; Moore, Tanlu and Bazerman, 2010; Ayal and Gino, 2012; Bazerman and Gino, 2012), who have been suggesting the need to examine conflicts of interests as a topic deserving of its own focus. Conceptually, the Stimulus-Organism-Response paradigm (Holt et al., 2015) that underlies the proposed cognitive model tends to offer a fresh perspective to address a wide range of behavioural concerns - this paradigm allows examining the cognitive processes as intervening variables (the organism dimension) between the situations involving conflict of interests as independent variable (the stimulus dimension) and the behaviour as dependent variable (the response dimension). Moreover, this study provides a direct focus on conflict of interests when most of the extant literature addresses this topic indirectly and, usually, in terms of the professionals' independence. The consideration of different categories provides strong empirical evidence for the observed relationships and helps ensure the stability of results across different conflict of 
interests. Following the empirical results, various testable propositions/hypotheses that have been offered for the relevant future research is yet another contribution.

Since the Big Four firms are considered the trendsetters in the professional accounting world and their policies also have an impact on the non-Big Fours, this study's findings and the new knowledge are of concern to all the professional accounting firms alike. The operationalisation of the behavioural variables included in the cognitive model and the vignettes developed for the experiment offer a ready-to-use research instrument for the future researchers. Importantly, this study has implications for existing practice since the professional accounting firms, accounting professionals and the regulators can use the new knowledge to make better decisions and to improve their policies. The findings invite the attention of the regulators and the policymakers who might consider revisions to their existing policies, by taking into consideration the much-needed behavioural insights. The proposed behavioural insights may be used as a guide to understanding the nature of the interventions that are particularly useful in addressing the professionals' independence in fact. Although this research provides empirical evidence from the professional accounting environment, the findings may also be applied to the law, engineering, medicine and architecture professions (Lo and Field, 2009) that are known to face the devastating impacts of conflict of interests.

However, despite the intended robustness of the proposed cognitive model, it should be considered that this study's 105 participants are limited in terms of the diversity in demographic characteristics $-79 \%$ are the partners, which implies a higher rank in their respective firm; $79 \%$ have more than 20 years of work experience, which implies higher work experience; $82 \%$ of the participants are more than 40 years old and $81 \%$ are male. Kish-Gephart, Harrison and Trevino (2010) conducted meta-analytic evidence about the sources of unethical decisions and found that, when examining decision-making behaviour, demographic variables become inconsequential once the other situational cognitive factors are accounted for. This study's cognitive model also accounts for situational cognitive factors and it can be argued that their effect dominates. The generalisations of this study's findings must still be made with caution. Future researchers might want to replicate this study with a diverse sample, more complex categories of conflict of interests, or in a different context. 


\section{References}

Afifah, U., Sari, R.N., Anugerah, R. and Sanusi, Z.M., 2015. The Effect of Role Conflict, Selfefficacy, Professional Ethical Sensitivity on Auditor Performance with Emotional Quotient as Moderating Variable. Procedia Economics and Finance, 31, pp.206-212.

Agle, B.R., Hart, D.W., Thompson, J.A. and Hendricks, H.M., 2014. Research Companion to Ethical Behavior in Organizations: Constructs and Measures. Cheltenham, UK; Northampton, MA: Edward Elgar Publishing Ltd.

Agnew, H., 2015. Professional Services: Accounting for Change. [online] 27 Aug. Available at: $<$ https://next.ft.com/content/938ed6c6-36e6-11e5-bdbb-35e55cbae175> [Accessed 31 Jul. 2016].

Ahmad, M., 2015. The impact of ex-auditors' employment with audit clients on perceptions of auditor independence in Malaysia. Procedia - Social and Behavioral Sciences, 172, pp.479486.

Allen, W.T. and Siegel, A., 2002. Threats and Safeguards in the Determination of Auditor Independence. Conflicts of Interest in Corporate and Securities Law, 80(2), pp.519-543.

Alloy, L.B. and Tabachnik, N., 1984. Assessment of covariation by humans and animals: the joint influence of prior expectations and current situational information. Psychological Review, 91(1), pp.112-149.

Anderson, J., 1985. Cognitive Psychology and its Implications. 2nd ed. [online] New York: Freeman. Available at: <http://act-r.psy.cmu.edu/?post_type=publications\&p=13830> [Accessed 12 Dec. 2016].

Argandona, A., 2004. Conflicts of interest: The ethical viewpoint. [IESE Research Paper] IESE Business School. Available at: <http://econpapers.repec.org/paper/ebgiesewp/d-0552.htm> [Accessed 21 Aug. 2013].

Ayal, S. and Gino, F., 2012. Honest rationales for dishonest behavior. In: M. Mikulincer and P.R. Shaver, eds., The social psychology of morality: Exploring the causes of good and evil, Herzliya series on personality and social psychology. Washington, DC, US: American Psychological Association, pp.149-166.

Baker-Eveleth, L. and Stone, R.W., 2008. Expectancy Theory and Behavioral Intentions to Use Computer Applications. Interdisciplinary Journal of Information, Knowledge, and Management, 3, pp.135-146.

Bakre, O.M. (2007) 'The Unethical Practices of Accountants and Auditors and the Compromising Stance of Professional Bodies in the Corporate World: Evidence from Corporate Nigeria'. Accounting Forum 31 (3), 277-303

Bandura, A., 1986. Social foundations of thought and action: A social cognitive theory. PrenticeHall series in social learning theory. Englewood Cliffs, NJ, US: Prentice-Hall, Inc. 
Bandura, A., Barbaranelli, C., Caprara, G.V. and Pastorelli, C., 1996. Mechanisms of Moral Disengagement in the Exercise of Moral Agency. ResearchGate, 71(2), pp.364-374.

Bandura, A., 1999. Moral Disengagement in the Perpetration of Inhumanities. ResearchGate, 3(3), pp.193-209.

Bandura, A., Caprara, G.-V. and Zsolnai, L., 2000. Corporate Transgressions Through Moral Disengagement. Journal of Human Values, 6(1), pp.57-64.

Bandura, A., 2002. Social Cognitive Theory in Cultural Context. Applied Psychology, 51(2), pp.269-290.

Bandura, A., 2006. Guide for Constructing Self-Efficacy Scales. In: Self-Efficacy Beliefs of Adolescents. Information Age Publishing, pp.307-337.

Bandura, A., 2008. Social Cognitive Theory. International encyclopedia of communication, 10, pp.4654-4659.

Bazerman, M.H. and Banaji, M.R., 2004. The Social Psychology of Ordinary Ethical Failures. Social Justice Research, 17(2), pp.111-115.

Bazerman, M.H. and Gino, F., 2012. Behavioral Ethics: Toward a Deeper Understanding of Moral Judgment and Dishonesty. Annual Review of Law and Social Science, 8, pp.85-104.

Beattie, V., Fearnley, S. and Brandt, R., 2005. Auditor Independence and Audit Risk: A Reconceptualisation. Journal of International Accounting Research, 4(1), pp.39-71.

Bedard, J.C., Deis, D.R., Curtis, M.B. and Jenkins, J.G., 2008. Risk Monitoring and Control in Audit Firms: A Research Synthesis. AUDITING: A Journal of Practice \& Theory, 27(1), pp.187-218.

Brown, J.L., Littlewood, R.A. and Vanable, P.A., 2013. Social-cognitive correlates of antiretroviral therapy adherence among HIV-infected individuals receiving infectious disease care in a medium-sized northeastern US city. AIDS care, 25(9), pp.1149-1158.

Bryman, A. and Bell, E., 2007. Business Research Methods. Oxford University Press.

Cain, D.M., Loewenstein, G. and Moore, D.A., 2005. Coming Clean but Playing Dirtier: The Shortcomings of Disclosure as a Solution to Conflicts of Interest. In: D.A. Moore, D.M. Cain, G. Lowenstein and M.H. Bazerman, eds., Conflicts of Interest: Challenges and Solutions in Business, Law, Medicine, and Public Policy. Cambridge University Press, p.104.

Cabrera-Frias, L., 2012. The ethics of professional skepticism in public accounting: how the auditor-client relationship impacts objectivity. [online] Georgetown University. Available at: $<$ https://repository.library.georgetown.edu/handle/10822/557686> [Accessed 2 Sep. 2016].

Casebeer, W.D. and Churchland, P.S., 2003. The Neural Mechanisms of Moral Cognition: A Multiple-Aspect Approach to Moral Judgement and Decision-Making. Biology and Philosophy, 18(1), pp.169-194. 
Charles, S.T., 2011. Emotional Experience and Regulation in Later Life. In: Handbook of the Psychology of Aging, Seventh. [online] Amsterdam: Academic Press, p.434. Available at: $<$ https://www.researchgate.net/publication/279718941_Chapter_19_Emotional_Experience_a nd_Regulation_in_Later_Life $>$ [Accessed 23 Dec. 2016].

Cheng, P.-Y. and Chu, M.-C., 2013. Behavioral Factors Affecting Students' Intentions to Enroll in Business Ethics Courses: A Comparison of the Theory of Planned Behavior and Social Cognitive Theory Using Self-Identity as a Moderator. Journal of Business Ethics, 124(1), pp.112.

Church, B.K., Jenkins, J.G., McCracken, S.A., Roush, P.B. and Stanley, J.D., 2015. Auditor Independence in Fact: Research, Regulatory, and Practice Implications Drawn from Experimental and Archival Research. Accounting Horizons, 29(1), pp.217-238.

Chugh, Banaji, M.R. and Bazerman, M.H., 2005. Conflicts of interest: Problems and solutions from law, medicine and organizational settings. London: Cambridge University Press.

Clements, C.E., Neill, J.D. and Stovall, O.S., 2012. Inherent Conflicts of Interest in the Accounting Profession. Journal of Applied Business Research (JABR), 28(2), pp.269-276.

Cohen, J.R. and Bennie, N.M., 2006. The Applicability of a Contingent Factors Model to Accounting Ethics Research. Journal of Business Ethics, 68(1), pp.1-18.

Conner, M., 2010. Cognitive Determinants of Health Behavior. In: A. Steptoe, ed., Handbook of Behavioral Medicine. [online] Springer New York, pp.19-30. Available at: $<$ http://link.springer.com/chapter/10.1007/978-0-387-09488-5_2> [Accessed 12 Dec. 2016].

Corcoran, K.J., 1991. Efficacy, 'skills,' reinforcement and choice behavior. American Psychologist, 46(2), pp.155-157.

Corcoran, K.J., 1995. Understanding cognition, choice and behavior. Journal of Behavior Therapy and Experimental Psychiatry, 26(3), pp.201-207.

Cozby, P.C. and Bates, S., 2011. Methods in Behavioral Research. 11 edition ed. New York, NY: McGraw-Hill Higher Education.

Creswell, J.W., 2014. Research design: Qualitative, Quantitative and Mixed methods approaches. Thousand Oaks, California: SAGE Publications.

Crump, R., 2013. FRC warns Auditors over Ethical Failings. [online] AccountancyAge. Available at: $\quad<$ http://www.accountancyage.com/aa/news/2271284/frc-warns-auditors-over-ethicalfailings $>$ [Accessed 2 Aug. 2013].

Crump, R., 2015. FRC hits KPMG with $£ 390,000$ in fines over ethical breaches. Accountancy Age. [online] 4 Feb. Available at: <https://www.accountancyage.com/aa/news/2393618/frchits-kpmg-with-gbp390-000-in-fines-over-ethical-breaches> [Accessed 31 Jul. 2016].

Cvejic, E., Lloyd, A.R. and Vollmer-Conna, U., 2016. Neurocognitive improvements after bestpractice intervention for chronic fatigue syndrome: Preliminary evidence of divergence 
between objective indices and subjective perceptions. Comprehensive Psychiatry, 66, pp.166175.

Davis, M., 1993. Conflict of Interest Revisited. Business and Professional Ethics Journal, 12(4), pp.21-41.

Dillman, D.A., Smyth, J.D. and Christian, L.M., 2008. Internet, Mail and Mixed-mode Surveys: The Tailored Design Method. 3rd Edition. Hoboken, N.J: John Wiley \& Sons.

Dopuch, N., King, R.R., Schwartz, R. and Zhang, P., 2003. Independence in Appearance and in Fact: An Experimental Investigation Discussion of 'Independence in Appearance and in Fact: An Experimental Investigation’. Contemporary Accounting Research, 20(1), pp.79-119.

Field, A., 2009. Discovering Statistics Using SPSS. Third Edition. Los Angeles: SAGE Publications Ltd.

Financial Reporting Council, 2016. Audit Quality Inspections Annual Report. [Inspections] Financial Reporting Council. Available at: <https://www.frc.org.uk/OurWork/Conduct/Audit-Quality-Review/Audit-Quality-Review-annual-reports.aspx>.

Finn, D.W., Chonko, L.B. and Hunt, S.D., 1988. Ethical problems in public accounting: The view from the top. Journal of Business Ethics, 7(8), pp.605-615.

Fishbein, M. and Cappella, J.N., 2006. The Role of Theory in Developing Effective Health Communications. Journal of Communication, 56, pp.S1-S17.

Fishbein, M., 2008. A Reasoned Action Approach to Health Promotion. Medical decision making: an international journal of the Society for Medical Decision Making, 28(6), pp.834-844.

Florio, C.V. di, 2012. Conflicts of Interest and Risk Governance. [online] US Securities and Exchange Commission. Available at: $<$ https://www.sec.gov/News/Speech/Detail/Speech/1365171491600> [Accessed 2 Sep. 2016].

Garcia, K. and Mann, T., 2003. From 'I Wish' to 'I Will': Social-cognitive Predictors of Behavioral Intentions. Journal of Health Psychology, 8(3), pp.347-360.

Greene, J.D., Sommerville, R.B., Nystrom, L.E., Darley, J.M. and Cohen, J.D., 2001. An fMRI investigation of emotional engagement in moral judgement. Science (New York, N.Y.), 293(5537), pp.2105-2108.

Green, D.P., Ha, S.E. and Bullock, J.G., 2010. Enough Already About 'Black Box' Experiments: Studying Mediation is More Difficult than Most Scholars Suppose. Annals of the American Academy of Political and Social Science, 628, pp.200-208.

Guiral, A., Rodgers, W., Ruiz, E. and Gonzalo, J.A., 2010. Ethical Dilemmas in Auditing: Dishonesty or Unintentional Bias? Journal of Business Ethics, 91(1), pp.151-166.

Hair, J.F., Ringle, C.M. and Sarstedt, M., 2013. Editorial - Partial Least Squares Structural Equation Modeling: Rigorous Applications, Better Results and Higher Acceptance. [SSRN 
Scholarly Paper] Rochester, NY: Social Science Research Network. Available at: $<$ http://papers.ssrn.com/abstract=2233795> [Accessed 1 Feb. 2016].

Henseler, J., Hubona, G. and Ray, P.A., 2016. Using PLS path modeling in new technology research: updated guidelines. Industrial Management \& Data Systems, 116(1), pp.2-20.

Holland, P.C., 2008. Cognitive versus stimulus-response theories of learning. Learning \& behavior, 36(3), pp.227-241.

Holt, N., Bremner, A., Sutherland, E., Vliek, M., Passer, M.W. and Smith, R.E., 2015. Psychology: The Science of Mind and Behaviour. 3 edition ed. McGraw-Hill Education / Europe, Middle East \& Africa.

IESBA, 2015. 2015 Handbook of the Code of Ethics for Professional Accountants. [online] International Federation of Accountants. Available at: <http://www.ethicsboard.org/> [Accessed 1 Apr. 2016].

Iskandar, T.M. and Sanusi, Z.M., 2011. Assessing the effects of self-efficacy and task complexity on internal control audit judgment. Asian Academy of Management Journal of Accounting and Finance, 7(1), pp.29-52.

Johnson, R.N. and Hansen, G.R., 2011. Audit Fees and Engagement Profitability. The CPA Journal.

Juhari, R.J., Mohd-Sanusi, Z., Rahman, R.A. and Omar, N.B., 2013. Auditors' Independence, Experience and Ethical Judgments: The Case of Malaysia. Journal of Business and Policy Research, 8(1), pp.100-119.

Kish-Gephart, J.J., Harrison, D.A. and Treviño, L.K., 2010. Bad apples, bad cases and bad barrels: meta-analytic evidence about sources of unethical decisions at work. The Journal of Applied Psychology, 95(1), pp.1-31.

Kock, N., 2011. WarpPLS 2.0 User manual. Laredo, Texas: ScriptWarp Systems.

Khan, S., Panatik, S.A., Saat, M.B.M. and Perveen, H., 2013. Auditors' Behavioral Intention Towards Dysfunctional Audit Behavior Applying Theory of Reasoned Action. [SSRN Scholarly Paper] Rochester, NY: Social Science Research Network. Available at: $<$ http://papers.ssrn.com/abstract=2701811> [Accessed 22 Aug. 2016].

Lin, M.-P., Ko, H.-C. and Wu, J.Y.-W., 2008. The Role of Positive/Negative Outcome Expectancy and Refusal Self-Efficacy of Internet Use on Internet Addiction among College Students in Taiwan. CyberPsychology \& Behavior, 11(4), pp.451-457.

Lo, B. and Field, M.J. eds., 2009. Conflict of Interest in Medical Research, Education and Practice. The National Academies Collection: Reports funded by National Institutes of Health. [online] Washington (DC): National Academies Press (US). Available at: $<$ http://www.ncbi.nlm.nih.gov/books/NBK22942/> [Accessed 17 Aug. 2013]. 
Loxton, L., 2015. How the Big Four have returned to consulting with a bang. Accountancy Age. [online] 27 Sep. Available at: $<$ https://www.accountancyage.com/aa/feature/2427739/featurehow-the-big-four-have-returned-to-consulting-with-a-bang $>$ [Accessed 2 Sep. 2016].

MacNab, B.R. and Worthley, R., 2008. Self-Efficacy as an Intrapersonal Predictor for Internal Whistleblowing: A US and Canada Examination. Journal of Business Ethics, 79(4), pp.407421.

Mills, S.K. and Bettner, M.S., 1992. Ritual and conflict in the audit profession. Critical Perspectives on Accounting, 3(2), pp.185-200.

Moore, D.A., Loewenstein, G., Tanlu, L. and Bazerman, M.H., 2003. Auditor independence, conflict of interest, and the unconscious intrusion of bias. Working paper / Division of Research, Harvard Business School; 03,116. Boston, Mass.

Moore, D.A. and Loewenstein, G., 2004. Self-Interest, Automaticity, and the Psychology of Conflict of Interest. Social Justice Research, 17(2), pp.189-202.

Moore, D.A., Cain, D.M., Loewenstein, G. and Bazerman, M.H., 2005. Conflicts of Interest: Challenges and Solutions in Business, Law, Medicine, and Public Policy. Cambridge University Press.

Moore, D.A., Tetlock, P.E., Tanlu, L. and Bazerman, M.H., 2006. Conflicts of Interest and The Case of Auditor Independence: Moral Seduction and Strategic Issue Cycling. Academy of Management Review, 31(1), pp.10-29.

Moore, C., 2008. Moral Disengagement in Processes of Organizational Corruption. Journal of Business Ethics, 80(1), pp.129-139.

Moore, D.A., Tanlu, L. and Bazerman, M., 2010. Conflict of Interest and the Intrusion of Bias. [online] Available at: <http://www.hbs.edu/faculty/Pages/item.aspx?num=37624 $>$ [Accessed 2 Apr. 2016].

Moore, C., Detert, J.R., Trevino, L.K., Baker, V.L. and Mayer, D.M., 2012. Why Employees Do Bad Things: Moral Disengagement and Unethical Organizational Behavior. Personnel Psychology, 65, pp.1-48.

Nelson, M.W., 2004. A Review of Experimental and Archival Conflicts-of-Interest Research in Auditing. [SSRN Scholarly Paper] Rochester, NY: Social Science Research Network. Available at: $<$ http://papers.ssrn.com/abstract=511383 $>$ [Accessed 15 Aug. 2014].

Nielsen, L.B., Mitchell, F., and Nørreklit, H. (2015) 'Management Accounting and Decision Making: Two Case Studies of Outsourcing'. Accounting Forum 39 (1), 64-82

Oseni, A.I., 2011. Unethical Behavior by Professional Accountant in an Organization. Research Journal of Finance and Accounting, 2(2), pp.106-111.

Palmer, N., 2013. The Effects of Leader Behavior on Follower Ethical Behavior: Examining the Mediating Roles of Ethical Efficacy and Moral Disengagement. Dissertations and Theses from 
the College of Business Administration. [online] Available at: $<\mathrm{http}: / /$ digitalcommons.unl.edu/businessdiss/40>.

Pierce, A., 2007. Ethics and the Professional Accounting Firm: A Literature Review. The Institute of Chartered Accountants of Scotland.

Rhemtulla, M., Brosseau-Liard, P.É. and Savalei, V., 2012. When Can Categorical Variables be treated as Continuous? A Comparison of Robust Continuous and Categorical SEM Estimation Methods under Suboptimal Conditions. Psychological Methods, 17(3), pp.354-373.

Rigotti, T., Schyns, B. and Mohr, G., 2008. A Short Version of the Occupational Self-Efficacy Scale: Structural and Construct Validity Across Five Countries. Journal of Career Assessment, 16(2), pp.238-255.

Rodgers, W., 1997. Throughput Modeling: Financial Information Used by Decision Makers. JAI Press Inc.

Rodgers, W., 2006. Process Thinking: Six Pathways to Successful Decision Making. iUniverse.

Rodgers, W., 2009. Ethical Beginnings: Preferences, Rules, and Principles Influencing Decision Making. iUniverse.

Rodgers, W. and Gago, S., 2001. Cultural and Ethical Effects on Managerial Decisions: Examined in a Throughput Model. Journal of Business Ethics, 31(4), pp.355-367.

Rodgers, W. and Gago, S., 2006. 'Biblical Scriptures Underlying Six Ethical Models Influencing Organizational Practices'. Journal of Business Ethics, 64(2), pp.125-136.

Rodgers, W. and AL Fayi, S. (2018) 'Ethical Pathways of Internal Audit Reporting Lines'. Accounting Forum [online] available from $<$ http://www.sciencedirect.com/science/article/pii/S0155998217302405> [26 January 2019].

Roth, S., 2012. Professional Accountants' Ethical Intent - The Impact of Job Role Beliefs and Professional Identity. [online] Available at: $<$ https://jyx.jyu.fi/dspace/handle/123456789/40871> [Accessed 17 Mar. 2016].

Salehi, M., 2009. In the Name of Independence: with Regard to Practicing Non-Audit Service by External Auditors. International Business Research, [online] 2(2). Available at: $<$ http://www.ccsenet.org/journal/index.php/ibr/article/view/1138> [Accessed 23 Jul. 2016].

Sauers, D.A., Ballentine, P. and Kennedy, J., 2006. Linking moral judgement and ethical decisionmaking: A cross-cultural comparison. Journal of Current Research in Global Business, 9, pp.20-27.

Saunders, M., Thornhill, A. and Lewis, P., 2009. Research Methods for Business Students. 5th edition ed. New York: Pearson Education.

Schuchter, A. and Levi, M. (2015) 'Beyond the Fraud Triangle: Swiss and Austrian Elite Fraudsters'. Accounting Forum 39 (3), 176-187 
Smith, N.C., Simpson, S.S. and Huang, C.-Y., 2007. Why Managers Fail to do the Right Thing: An Empirical Study of Unethical and Illegal Conduct. Business Ethics Quarterly, 17(4), pp.633-667.

Sniehotta, F.F., Schwarzer, R., Scholz, U. and Schüz, B., 2005. Action planning and coping planning for long-term lifestyle change: Theory and assessment. ResearchGate, 35(4), pp.565576.

Sullivan, G., 2004. Enhancing Public Trust in the Accounting Profession Using Professional Judgement Rather Than Personal Judgement in Resolving Accounting Ethics Dilemmas. Faculty Dissertations. [online] Available at: $<$ http://digitalcommons.liberty.edu/fac_dis/39>.

Sutton, S., 1998. Predicting and Explaining Intentions and Behavior: How Well Are We Doing? Journal of Applied Social Psychology, 28(15), pp.1317-1338.

Tepalagul, N. and Lin, L., 2014. Auditor Independence and Audit Quality A Literature Review. Journal of Accounting, Auditing \& Finance, 30(1), pp.101-121.

Thagard, P., 2007. The Moral Psychology of Conflicts of Interest: Insights from Affective Neuroscience. Journal of Applied Philosophy, 24(4), pp.367-8211.

Williford, K. and Small, D., 2013. Establishing an Effective Compliance Program: An Overview to Protecting Your Organization. [online] Association of Corporate Counsel. Available at: $<$ http://www.acc.com/legalresources/quickcounsel/eaecp.cfm $>$ [Accessed 2 Sep. 2016].

Williams, D.M., 2010. Outcome expectancy and self-efficacy: theoretical implications of an unresolved contradiction. Personality and Social Psychology Review: An Official Journal of the Society for Personality and Social Psychology, Inc, 14(4), pp.417-425.

Wongpinunwatana, N. and Panchoo, P., 2014. Creating Self-Efficacy In Internal Auditors For Information Technology Audits: An On-The-Job Training Perspective. International Journal of Management \& Information Systems (IJMIS), 18(3), pp.213-222.

Zebracki, K. and Drotar, D., 2004. Outcome Expectancy and Self-Efficacy in Adolescent Asthma Self-Management. Children's Health Care, 33(2), pp.133-149. 


\section{Appendix 1: Interview Questions}

Q1. Could you please describe the audit engagement process followed in your firm?

- What factors are considered when accepting a client?

- What is the composition of audit engagement teams?

- Could you please brief me on the decision-making process during engagements?

Q2. What type of rewards and pressures/incentives and disincentives do you think auditors might receive within the environment of audit firms they are working in?

Q3. Do you think auditor's performance and decision-making can be affected in case of specific rewards which are not aligned with the primary interest of audit profession i.e. to act in the best interest of public? How? Examples.

Q4. Do you think the workplace pressures contradicting with primary interest can impact an auditor's performance and decision-making? How? Examples.

Q5. Is conflict of interests a negative phenomenon as generally presumed, or are these a natural phenomenon that needs effective management?

Q6. What regulations, measures and/or frameworks does your firm adopt to manage conflict of interests?

- External

- Internal

- How effective are those existing measures in practice?

Q7. Have you ever personally experienced or observed a situation that involved a conflict of interests? Would you mind sharing that experience?

- How do you think the conflict of interests can affect your mindset and perceptions? Example.

Q8. What do you think could be the reason(s) that might lead a professional auditor to not do complete justice to their primary responsibility of serving in the best interest of public (i.e. provision of appropriate audit opinion), despite his/her very good intentions? 


\section{Appendix 2: Research Instrument*}

\section{INTRODUCTION}

The entire study comprises of two brief phases and takes about 15 minutes to complete. You can either complete it in one go or, alternatively, do a part of the study now and return later to continue from where you last left it.

Please click 'Next' to start. Happy Participation!

\section{PHASE-1}

In this phase, you will be requested to first provide information on some demographics (which will be used anonymously during data analysis) and then to respond to some measures related to behaviour.

\section{Demographics}

i. Your Rank(s) in the Firm

口 Management Board

口 Partner

$\square$ Director

口 Statutory Auditor

$\square$ Other, please specify

ii. Gender $\quad$ Male $\quad$ Female

iii. Years of

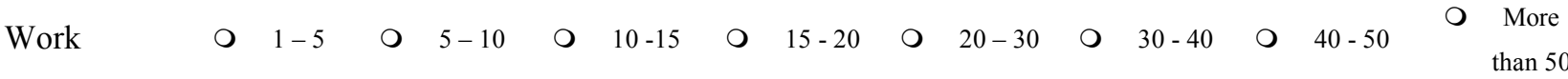
Experience

iv. Age (in years)

O $20-30 \bigcirc 30-40 \quad \bigcirc \quad 40-50 \quad \bigcirc \quad 50-60$

O More than 60

Please indicate how true is the following about you?

\begin{tabular}{|c|c|c|c|c|c|}
\hline Particulars & $\begin{array}{c}\text { Not at all True } \\
\mathbf{1}\end{array}$ & $\mathbf{2}$ & $\mathbf{3}$ & $\mathbf{4}$ & \begin{tabular}{c} 
Completely True \\
\hline $\begin{array}{c}\text { I can remain calm } \\
\text { when facing } \\
\text { difficulties in my } \\
\text { job because I can } \\
\text { rely on my abilities }\end{array}$
\end{tabular} \\
\hline $\begin{array}{c}\text { When I am } \\
\text { confronted with a } \\
\text { problem in my job, }\end{array}$ & 0 & 0 & 0 & 0 & 0 \\
\hline
\end{tabular}




\begin{tabular}{|c|c|c|c|c|c|}
\hline $\begin{array}{c}\text { I can usually find } \\
\text { several solutions }\end{array}$ & O & 0 & 0 & 0 & 0 \\
\hline $\begin{array}{c}\text { Whatever comes } \\
\text { my way in my job, } \\
\text { I can usually } \\
\text { handle it }\end{array}$ & 0 & 0 & 0 & 0 & 0 \\
\hline $\begin{array}{c}\text { My past } \\
\text { experiences in my } \\
\text { job have prepared } \\
\text { me well for my } \\
\text { occupational future }\end{array}$ & 0 & 0 & 0 & 0 & 0 \\
\hline $\begin{array}{c}\text { I meet the goals } \\
\text { that I set for } \\
\text { myself in my job }\end{array}$ & 0 & 0 & 0 & 0 & 0 \\
\hline $\begin{array}{c}\text { I feel prepared for } \\
\text { most of the } \\
\text { demands in my job }\end{array}$ & 0 & & & \\
\hline
\end{tabular}

Please indicate your level of agreement/disagreement with the following;

\begin{tabular}{|c|c|c|c|c|c|}
\hline Particulars & $\begin{array}{c}\text { Strongly Disagree } \\
1\end{array}$ & 2 & 3 & 4 & $\begin{array}{c}\text { Strongly Agree } \\
5\end{array}$ \\
\hline $\begin{array}{l}\text { It is okay to spread } \\
\text { rumours to defend } \\
\text { those you } \\
\text { care about }\end{array}$ & 0 & O & O & 0 & 0 \\
\hline $\begin{array}{l}\text { Taking something } \\
\text { without the owner's } \\
\text { permission is okay } \\
\text { as long as you're } \\
\text { just borrowing it }\end{array}$ & O & O & O & 0 & 0 \\
\hline $\begin{array}{l}\text { Considering the } \\
\text { ways people grossly } \\
\text { misrepresent } \\
\text { themselves, it's } \\
\text { hardly a sin to } \\
\text { inflate your own } \\
\text { credentials a bit }\end{array}$ & O & O & O & O & 0 \\
\hline $\begin{array}{l}\text { People shouldn't be } \\
\text { held accountable } \\
\text { for doing } \\
\text { questionable things } \\
\text { when they were just } \\
\text { doing what an } \\
\text { authority figure told } \\
\text { them to do }\end{array}$ & 0 & O & O & O & 0 \\
\hline
\end{tabular}




\begin{tabular}{|c|c|c|c|c|c|}
\hline $\begin{array}{c}\text { People can't be } \\
\text { blamed for doing } \\
\text { things that are } \\
\text { technically wrong } \\
\text { when all their } \\
\text { friends are doing it } \\
\text { too }\end{array}$ & 0 & 0 & 0 & 0 & 0 \\
\hline $\begin{array}{c}\text { Taking personal } \\
\text { credit for ideas that } \\
\text { were not your } \\
\text { own is no big deal }\end{array}$ & 0 & 0 & 0 & 0 & 0 \\
\hline $\begin{array}{c}\text { Some people have } \\
\text { to be treated } \\
\text { roughly because } \\
\text { they lack feelings } \\
\text { that can be hurt }\end{array}$ & 0 & 0 & 0 & 0 & 0 \\
\hline $\begin{array}{c}\text { People who get } \\
\text { mistreated have } \\
\text { usually done } \\
\text { something to bring } \\
\text { it on themselves }\end{array}$ & 0 & 0 & 0 & 0 & \\
\hline
\end{tabular}

PHASE-2

In this phase, you will be presented with four very simple and brief vignettes comprising of different situations. You will be requested to respond to the measures included in each of these.

\section{VIGNETTE 1}

"You are a junior accountant and currently a part of a team providing audit and non-audit services to your firm's client that deals in home improvement and renovation materials. During the engagement, you told the client's controller that you are remodelling an old house. The controller likes you and had a load of needed materials delivered to your house, billing you at a $70 \%$ discount — saving you quite a lot above the normal cash discount. You are very happy to have the materials, which you otherwise would not have been able to afford on your insufficient salary. Your colleagues and seniors have always found you a very professional and vigilant employee who never ever lets personal affairs affect the work-related responsibilities".

Keeping in mind the situation (scenario and role/rank assigned to you), please respond to the following by indicating your choice from the drop-down options;

\begin{tabular}{|c|c|c|c|c|c|}
\hline $\begin{array}{c}\text { Given the situation, } \\
\text { what is the level of } \\
\text { difficulty in } \\
\text { refusing to } \\
\text { accept the offered } \\
70 \% \text { discount? }\end{array}$ & O Very Difficult & O Difficult & O Neutral & O Easy & Very Easy \\
\hline
\end{tabular}




\begin{tabular}{|c|c|c|c|c|c|c|c|c|c|c|}
\hline $\begin{array}{l}\text { Given the situation, } \\
\text { I expect the overall } \\
\text { positive outcomes } \\
\text { of declining the } \\
\text { offered } 70 \% \text { discou } \\
\text { nt to outweigh its } \\
\text { overall negative } \\
\text { outcomes }\end{array}$ & o & $\begin{array}{l}\text { Strongly } \\
\text { Disagree }\end{array}$ & 0 & Disagree & O & $\begin{array}{l}\text { Neither Agree } \\
\text { nor Disagree }\end{array}$ & 0 & Agree & 0 & $\begin{array}{c}\text { Strongly } \\
\text { Agree }\end{array}$ \\
\hline $\begin{array}{c}\text { Given the } \\
\text { situation, I might be } \\
\text { willing to accept the } \\
\text { offered } 70 \% \\
\text { discount }\end{array}$ & O & $\begin{array}{c}\text { Extremely } \\
\text { Unlikely }\end{array}$ & O & Unlikely & $c$ & Neutral & 0 & Likely & 0 & $\begin{array}{c}\text { Extremely } \\
\text { Likely }\end{array}$ \\
\hline $\begin{array}{c}\text { Given the } \\
\text { situation, I will be } \\
\text { able to decline the } \\
\text { offered } 70 \% \\
\text { discount and will } \\
\text { avail only the } \\
\text { normal cash } \\
\text { discount }\end{array}$ & 0 & $\begin{array}{c}\text { Extremely } \\
\text { Unlikely }\end{array}$ & O & Unlikely & $c$ & Neutral & O & Likely & 0 & $\begin{array}{c}\text { Extremely } \\
\text { Likely }\end{array}$ \\
\hline $\begin{array}{c}\text { Regardless of } \\
\text { whichever decision } \\
\text { ( } 3 \text { or } 4 \text { above) } \\
\text { is more likely to } \\
\text { take place in a given } \\
\text { situation, which } \\
\text { according to you is } \\
\text { ethically } \\
\text { more appropriate? }\end{array}$ & O & $\begin{array}{c}\text { Acceptance of } \\
\text { offered } 70 \% \\
\text { discount }\end{array}$ & & $\begin{array}{l}\text { Both can be } \\
\text { appropriate if } \\
\text { principles of } \\
\text { professional } \\
\text { ethics are not } \\
\text { compromised }\end{array}$ & O & $\begin{array}{l}\text { Declining the } \\
\text { offered } 70 \% \\
\text { discount }\end{array}$ & & & & \\
\hline
\end{tabular}

\section{VIGNETTE 2}

"During an assurance engagement, your immediate supervisor is on sick leave and you are due to go on parental leave in 3 days' time. Your firm is facing exceptionally challenging times and is not able to engage any other accountant on this assignment. You have been told by the top management that, before you go on leave, you must complete some complicated reconciliation work. Given the complexity of work, the deadline suggested (i.e. 2 days) appears very unrealistic. You feel that you are not sufficiently experienced to complete the work alone and that you need additional supervision to complete it to the required standard. The top management appears unable to offer the necessary support. Furthermore, neither the deadline can be extended, nor can you postpone your leave. You fear losing your own and your firm's reputation, should you refuse to perform the assigned task. You feel very intimidated by the top management and feel pressure to do whatever you can in your firm's challenging times". Keeping in mind the situation (scenario and role/rank assigned to you), please respond to the following by indicating your choice from the drop-down options;

\begin{tabular}{|c|c|c|c|c|c|c|}
\hline $\begin{array}{c}\text { Given the situation, } \\
\text { what is the level of } \\
\text { difficulty in }\end{array}$ & $\circ$ Very Difficult & O Difficult & O Neutral & O Easy & O Very Easy \\
\hline
\end{tabular}




\begin{tabular}{|c|c|c|c|c|c|c|c|c|c|c|}
\hline $\begin{array}{l}\text { refusing to perform } \\
\text { the task? }\end{array}$ & & & & & & & & & & \\
\hline $\begin{array}{l}\text { Given the situation, } \\
\text { I expect the overall } \\
\text { positive outcomes } \\
\text { of refusing to } \\
\text { perform the task to } \\
\text { outweigh its overall } \\
\text { negative outcomes }\end{array}$ & O & $\begin{array}{l}\text { Strongly } \\
\text { Disagree }\end{array}$ & O & Disagree & O & $\begin{array}{l}\text { Neither Agree } \\
\text { nor Disagree }\end{array}$ & 0 & Agree & O & $\begin{array}{l}\text { Strongly } \\
\text { Agree }\end{array}$ \\
\hline $\begin{array}{c}\text { Given the } \\
\text { situation, I will } \\
\text { agree to work alone } \\
\text { and will try my } \\
\text { level best to } \\
\text { complete the task } \\
\text { assigned to me }\end{array}$ & O & $\begin{array}{l}\text { Extremely } \\
\text { Unlikely }\end{array}$ & O & Unlikely & c & Neutral & $\mathrm{O}$ & Likely & 0 & $\begin{array}{c}\text { Extremely } \\
\text { Likely }\end{array}$ \\
\hline $\begin{array}{c}\text { Given the } \\
\text { situation, I will } \\
\text { refuse to perform } \\
\text { the task assigned to } \\
\text { me }\end{array}$ & O & $\begin{array}{l}\text { Extremely } \\
\text { Unlikely }\end{array}$ & O & Unlikely & & Neutral & O & Likely & 0 & $\begin{array}{c}\text { Extremely } \\
\text { Likely }\end{array}$ \\
\hline $\begin{array}{c}\text { Regardless of } \\
\text { whichever decision } \\
\text { ( } 3 \text { or } 4 \text { above) } \\
\text { is more likely to } \\
\text { take place in a } \\
\text { given situation, } \\
\text { which according to } \\
\text { you is ethically } \\
\text { more appropriate? }\end{array}$ & O & $\begin{array}{l}\text { Agreeing to } \\
\text { work alone }\end{array}$ & & $\begin{array}{l}\text { Both can be } \\
\text { appropriate if } \\
\text { principles of } \\
\text { professional } \\
\text { ethics are not } \\
\text { compromised }\end{array}$ & O & $\begin{array}{l}\text { Refusing to } \\
\text { perform the } \\
\text { task }\end{array}$ & & & & \\
\hline
\end{tabular}

\section{VIGNETTE 3}

"You are a junior accountant charged with evaluation of internal control system of your firm's client. You evaluated and reported the system as very effective and also received bonus and appreciations for your hard work. Now during the audit of the same client, you have discovered that internal control system is not as effective as you evaluated since there are some minor weaknesses that you overlooked. You are concerned that nullifying your previous evaluation will be discrediting and will affect your expected promotion and pay rise right after the audit. You are completely sure that no one else from the audit team is going to find out about those minor weaknesses in the internal control system of the client".

Keeping in mind the situation (scenario and role/rank assigned to you), please respond to the following by indicating your choice from the drop-down options;

\begin{tabular}{|c|c|c|c|c|c|c|}
\hline $\begin{array}{c}\text { Given the situation, } \\
\text { what is the level of } \\
\text { difficulty in }\end{array}$ & O Very Difficult & $\bigcirc$ Difficult & O Neutral & O Easy & O Very Easy \\
\hline
\end{tabular}




\begin{tabular}{|c|c|c|c|c|c|c|c|c|c|c|}
\hline $\begin{array}{l}\text { accepting your } \\
\text { negligence in } \\
\text { initial evaluation of } \\
\text { the internal control } \\
\text { system of the client? }\end{array}$ & & & & & & & & & & \\
\hline $\begin{array}{c}\text { Given the } \\
\text { situation, I expect } \\
\text { the overall positive } \\
\text { outcomes of } \\
\text { disclosing my } \\
\text { negligence in initial } \\
\text { evaluation to } \\
\text { outweigh its overall } \\
\text { negative outcomes }\end{array}$ & O & $\begin{array}{l}\text { Strongly } \\
\text { Disagree }\end{array}$ & O & Disagree & & $\begin{array}{c}\text { Neither Agree } \\
\text { nor Disagree }\end{array}$ & O & Agree & O & $\begin{array}{l}\text { Strongly } \\
\text { Agree }\end{array}$ \\
\hline $\begin{array}{l}\text { Keeping in mind the } \\
\text { bonus \& } \\
\text { appreciations receiv } \\
\text { ed and the } \\
\text { opportunity of } \\
\text { promotion and pay } \\
\text { rise, I might not be } \\
\text { able to disclose the } \\
\text { minor weaknesses } \\
\text { in internal control } \\
\text { system of the client }\end{array}$ & O & $\begin{array}{l}\text { Extremely } \\
\text { Unlikely }\end{array}$ & O & Unlikely & & Neutral & O & Likely & 0 & $\begin{array}{c}\text { Extremely } \\
\text { Likely }\end{array}$ \\
\hline $\begin{array}{l}\text { No matter how } \\
\text { discrediting it is, I } \\
\text { will admit } \\
\text { negligence in my } \\
\text { initial evaluation of } \\
\text { internal control } \\
\text { system of the client }\end{array}$ & O & $\begin{array}{l}\text { Extremely } \\
\text { Unlikely }\end{array}$ & O & Unlikely & & Neutral & O & Likely & O & $\begin{array}{c}\text { Extremely } \\
\text { Likely }\end{array}$ \\
\hline $\begin{array}{l}\text { Regardless of } \\
\text { whichever decision } \\
\text { ( } 3 \text { or } 4 \text { above) } \\
\text { is more likely to } \\
\text { take place in a given } \\
\text { situation, which } \\
\text { according to you is } \\
\text { ethically more } \\
\text { appropriate? }\end{array}$ & & $\begin{array}{l}\text { Admitting } \\
\text { Minor } \\
\text { weaknesses } \\
\text { might be } \\
\text { ignored }\end{array}$ & & $\begin{array}{l}\text { Both can be } \\
\text { appropriate if } \\
\text { principles of } \\
\text { professional } \\
\text { ethics are not } \\
\text { compromised }\end{array}$ & O & $\begin{array}{l}\text { Admitting } \\
\text { negligence }\end{array}$ & & & & \\
\hline
\end{tabular}

\section{VIGNETTE 4}

"You are a partner in a firm of accountants engaged in preparing year end accounts and tax returns for one of your biggest, friendliest and the trustworthy client companies. During the engagement, you become aware that staff purchases of goods manufactured by the company are authorised by production managers and then processed outside the accounting system. The client company uses the proceeds from these sales to fund its Christmas party. The practice is in place since three years but your firm failed to find this in the previous years while providing 
same services to the client. You are concerned that omitting the income from staff sales will result in the financial statements and returns to the tax authority being misleading. The client is willing to correctly record the sales for the current year, but they requested you to ignore the improper accounting in previous years as they were not aware of the proper treatment. You and the other higher authorities in your firm also believe that highlighting the mistakes from previous years will not only affect good terms with the client but will also reveal your firm's negligence in discovering the issue in earlier years which, in turn, will badly affect the firm's reputation. You are also considerate of the high proportion of fees generated through services provided to the client".

Keeping in mind the situation (scenario and role/rank assigned to you), please respond to the following by indicating your choice from the drop-down options;

\begin{tabular}{|c|c|c|c|c|c|c|c|c|c|c|}
\hline $\begin{array}{l}\text { Given the situation, } \\
\text { what is the level of } \\
\text { difficulty in } \\
\text { disclosing the past } \\
\text { undisclosed income } \\
\text { to tax authorities? }\end{array}$ & 0 & Very Difficult & O & Difficult & o & Neutral & 0 & Easy & O & Very Easy \\
\hline $\begin{array}{l}\text { Given the } \\
\text { situation, I expect } \\
\text { the overall positive } \\
\text { outcomes of } \\
\text { disclosing the past } \\
\text { undisclosed income } \\
\text { to tax authorities to } \\
\text { outweigh its overall } \\
\text { negative outcomes }\end{array}$ & o & $\begin{array}{l}\text { Strongly } \\
\text { Disagree }\end{array}$ & O & Disagree & & $\begin{array}{c}\text { Neither Agree } \\
\text { nor Disagree }\end{array}$ & 0 & Agree & 0 & $\begin{array}{c}\text { Strongly } \\
\text { Agree }\end{array}$ \\
\hline $\begin{array}{c}\text { Given the } \\
\text { situation, I will } \\
\text { dissociate myself } \\
\text { from any } \\
\text { involvement with } \\
\text { client's financial } \\
\text { statements, but it } \\
\text { might not be } \\
\text { practical to report } \\
\text { the matter to tax } \\
\text { authorities }\end{array}$ & 0 & $\begin{array}{l}\text { Extremely } \\
\text { Unlikely }\end{array}$ & 0 & Unlikely & a & Neutral & 0 & Likely & 0 & $\begin{array}{c}\text { Extremely } \\
\text { Likely }\end{array}$ \\
\hline $\begin{array}{c}\text { No matter how my } \\
\text { co-partners react, I } \\
\text { will report the } \\
\text { matter to tax } \\
\text { authorities }\end{array}$ & 0 & $\begin{array}{c}\text { Extremely } \\
\text { Unlikely }\end{array}$ & O & Unlikely & o & Neutral & O & Likely & O & $\begin{array}{c}\text { Extremely } \\
\text { Likely }\end{array}$ \\
\hline $\begin{array}{l}\text { Regardless of } \\
\text { whichever decision } \\
\text { ( } 3 \text { or } 4 \text { above) } \\
\text { is more likely to } \\
\text { take place in a } \\
\text { given situation, }\end{array}$ & O & $\begin{array}{c}\text { Not reporting } \\
\text { to tax } \\
\text { authority }\end{array}$ & & $\begin{array}{l}\text { Both can be } \\
\text { appropriate if } \\
\text { principles of } \\
\text { professional } \\
\text { ethics are not } \\
\text { compromised }\end{array}$ & & $\begin{array}{c}\text { Reporting } \\
\text { matter to tax } \\
\text { authority }\end{array}$ & & & & \\
\hline
\end{tabular}




\begin{tabular}{|c|l|l|l|l|l|}
\hline $\begin{array}{c}\text { which according to } \\
\text { you is ethically } \\
\text { more appropriate? }\end{array}$ & & & & & \\
\hline
\end{tabular}

Comments, if any

DONE! Please click 'Submit the Responses' at the bottom right corner

* The original layout (web-based), developed using Qualtrics, is far more compact and attractive than it appears here (on paper). 


\section{Appendix 3: Model Assessment Criteria}

Insert Table A1: Coefficients of determination $\left(R^{2}\right)$ here

Insert Table A2: Effect Sizes $\left(f^{2}\right)$ here

Insert Table A3: Predictive Relevance $\left(Q^{2}\right)$ here

Insert Table A4: Goodness of Fit-SRMR here

Insert Table A5: Multicollinearity - Variance Inflation Factors (VIFs) here 